\title{
Macroalgal biorefinery concepts for the circular bioeconomy: A review on biotechnological developments and future perspectives
}

\author{
Emily T. Kostas ${ }^{\text {a, }}$, Jessica M.M. Adams ${ }^{\text {b }}$, Héctor A. Ruiz ${ }^{\mathrm{c}}$, Gabriela Durán-Jiménez ${ }^{\text {d, }}$ \\ Gary J. Lye ${ }^{\mathrm{a}}$ \\ ${ }^{a}$ The Advanced Centre of Biochemical Engineering, Department of Biochemical Engineering, University College London, Gower Street, London, WC1E 6BT, UK \\ ${ }^{\mathrm{b}}$ Institute of Biological, Environmental and Rural Sciences, Aberystwyth University, Gogerddan, Aberystwyth, Ceredigion, SY23 3EE, UK \\ ${ }^{\mathrm{c}}$ Biorefinery Group, Food Research Department, Faculty of Chemistry Sciences, Autonomous University of Coahuila, Saltillo, Coahuila, 25280, Mexico \\ ${ }^{\mathrm{d}}$ Faculty of Engineering, The University of Nottingham, Nottingham, NG7 2RD, UK
}

\section{A R T I C L E I N F O}

\section{Keywords:}

Seaweed

Biomass

Bioproducts

Bioprocessing

Biotechnology

Biorefinery

\begin{abstract}
A B S T R A C T
The imminent need for transition to a circular bioeconomy, based on the valorisation of renewable biomass feedstocks, will ameliorate global challenges induced by climate change, environmental pollution and population growth. A reduced reliance on depleting fossil fuel resources and ensured production of eco-friendly and costeffective bioproducts and biofuels, requires the development of sustainable biorefinery processes, with many utilising macroalgae as feedstock, showing promising and viable prospects. Nonetheless, macroalgal biorefinery research is still in its infancy compared to lignocellulosic biorefineries that utilise terrestrial plants. This article presents a review on the latest scientific literature associated with the development and status of macroalgal biorefineries, and how bioproducts generated from these bioprocesses have contributed towards the bioeconomy. The fundamental need to understand how the unique biochemical composition of macroalgae fit within a biorefinery concept are explained, alongside discussion of the novel biotechnologies that have been applied. In order to comprehend the increasing significance of this exciting field, the review will also provide insight, for the first time, on the current global funding and intellectual property landscape related to macroalgae and their implementation across the entire biorefinery concept. Imperative areas for further research and development, to bridge the gap between fundamental bioscience in the laboratory and the successful application of compatible biotechnologies at a commercial scale, to boost the macroalgae industry are also covered.
\end{abstract}

\section{Introduction}

There are many challenges that our planet is currently facing which include climate change, an increase in global population (expected to reach 9.7 billion by 2050 [1]), as well as issues surrounding the growing demand for food, natural resources and raw materials [2]. In order to maintain global economic growth whilst simultaneously minimising negative impacts on the environment and preserving natural resources, the utilisation of renewable feedstocks as an alternative to fossil fuels require immediate and more widespread adoption. This would also involve the application of alternative clean energies and renewable inputs into production processes, to ultimately enable societies to transition towards a biobased bioeconomy [3]. As such, interest in promoting the bioeconomy is reflected by the number of countries and organisations worldwide that are currently pursuing explicit policies and strategies, to expand their bioeconomies, in order to achieve as many of the 17 Sustainable Development Goal's (SDG) set by the United Nations (UN) as possible [4,5]. For example, the European Union (EU) revised their bioeconomy strategy in 2018 to put greater emphasis on the three pillars of sustainability: 'economy, society and environment' to align better with the UN's SDGs [6,7]. The UK government also released its own strategy that aims to double its bioeconomy spending from $£ 220$ billion to $£ 440$ billion by 2030 [8].

The biorefining of biomass feedstocks for the production of marketable products such as food, animal feed, chemicals, materials and energy (in the forms of biofuels, power and/or heat) via eco-innovative and sustainable bioprocess systems align with a number of the SDGs [5]. Due to the fact that biomass is of biogenic origin, any $\mathrm{CO}_{2}$ released from the biomass via different biochemical processes does not contribute towards an increase in atmospheric $\mathrm{CO}_{2}$ [9]. Macroalgae (seaweeds), an underutilised yet attractive resource, are known to not only play a key

\footnotetext{
* Corresponding author.

E-mail address: e.kostas@ucl.ac.uk (E.T. Kostas).
} 


\begin{tabular}{|lll|}
\hline \multicolumn{2}{|l|}{ Abbreviations } & spp $\quad$ Species \\
UN & United Nations & HTL Hydrothermal liquefaction \\
EU & European Union & D. tenuissima Derbesia tenuissima \\
EC & European Commission & U. ohnoi Ulva ohnoi \\
U.S DoE & United States Department of Energy & U. lactuca Ulva lactuca \\
SDG & Sustainable Development Goals & U. fasciata Ulva fasciata \\
LCA & Life Cycle Analysis & C. linum Chaetomorpha linum \\
TEA & Technoeconomic Analysis & S. muticum Sargassum muticum \\
dw & Dry Weight & L. digitata Laminaria digitata \\
IMTA & Integrated Multi Trophic Aquaculture & L. hyperborea Laminaria hyperborea \\
m & Million & F. spiralis Fucus spiralis \\
bn & Billion & S. latissima Saccharina latissima \\
& & S. cerevisiae Saccharomyces cerevisiae \\
\hline
\end{tabular}

ecological role in coastal ecosystems, but through sustainable cultivation approaches, they may also have the potential to address global challenges. These include issues related to food consumption, agriculture, human health and coastal management; all of which, if efficiently implemented, would contribute towards a sustainable circular bioeconomy with enhanced growth [10]. Compared to lignocellulosic feedstocks, which have represented a cornerstone of the bioeconomy to date [11], macroalgae are potentially more suited for biorefinery processes due to their large biomass yields, fast growth rates and absence of terrestrial land requirements for cultivation [12]. Their lack of a recalcitrant lignocellulosic structure [13] implies that less energy intensive bioprocesses can be applied to recover high value bioproducts of commercial interest; this would favour life cycle and techno-economic analyses (LCA and TEA) of any putative biorefinery process that employs macroalgae as a feedstock. Furthermore, the presence of speciality polysaccharides that are inherent to macroalgal species belonging to the three different taxonomical groups offer unique properties for either direct use and/or as platform biocompounds for the bioeconomy.

Despite the clear advantages macroalgal species offer, and their potential to be implemented within a biorefinery, both the research and commercialisation aspects of macroalgal biorefineries are still in their infancy and few have progressed beyond laboratory scale. Fig. 1 shows the number of scientific publications related to biorefinery processes utilising lignocellulosic biomass compared to macroalgae that appeared between 1993-July 2021.

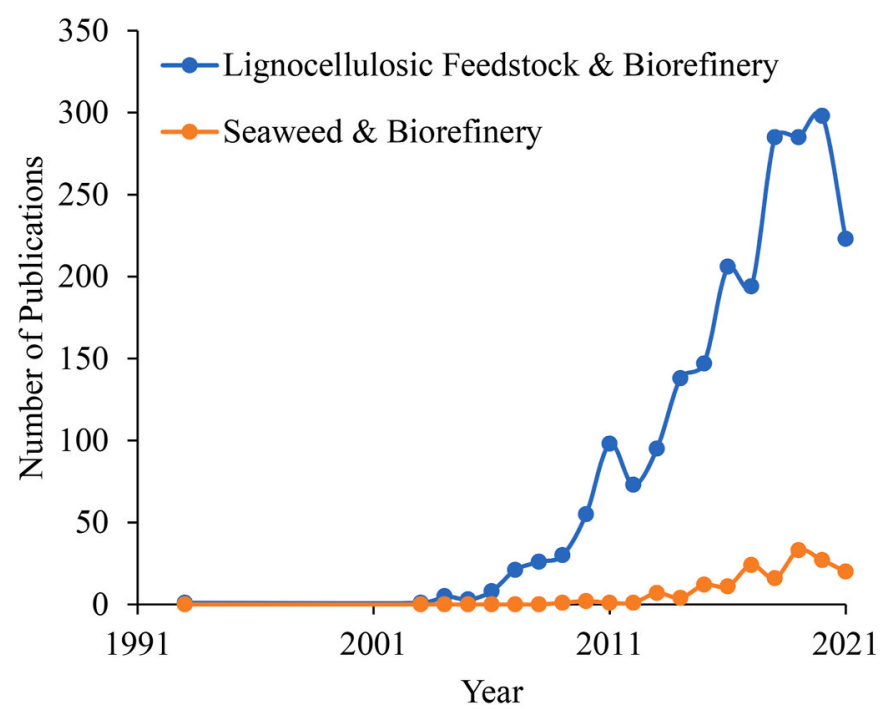

Fig. 1. Evolution of the number of scientific publications related to macroalgae or lignocellulosic biorefineries during 1993-2021 (July 2021) (keywords: 'macroalgae' or 'lignocellulosic' AND 'biorefinery') (Source: Scopus $\left.{ }^{\circledR}\right)$.
It is evident that the myriad of publications related to lignocellulosic feedstocks continue to surpass macroalgae biorefinery research year-onyear. This stems from the first and second-generation biofuel revolution, which drove global bioethanol research from the early 1970s using terrestrial plants and waste residues [14]. The use of macroalgae are considered to be third or even 4th/advanced generation feedstocks [15], and research interests utilising macroalgae began to increase once hindrances associated with lignocellulosic biomass began to surface, mainly the high costs and harsh thermochemical pretreatments that are required. Unfortunately, the biotechnologies originally designed for lignocellulosic feedstocks have proved to be incompatible with the unique biochemical composition of macroalgal biomass and could therefore not be applied [16]. Consequently, new lines of research had to commence for the development of novel macroalgal specific bioprocesses. Nevertheless, the scientific interest and industrial applications of macroalgae continue to increase which has ultimately aided the production of 31 million tonnes of macroalgae (fresh weight) per annum, worth an estimated market value of USD400 per tonne (dry weight) [17].

Macroalgal biorefinery systems, once fully optimised, have the potential to economically strengthen a number of industrial sectors whilst helping the circular bioeconomy and mitigate climate change. This awareness has led to the establishment of a promising 2020 manifesto 'Seaweed Revolution: A manifesto for a sustainable future' led by the Lloyd's Register Foundation together with the UN's Global Compact's Action Platform for Sustainable Ocean Business. This essentially outlines the potential of macroalgae to deliver on the UN's sustainable development goals, including a contribution to food safety and security, climate change mitigation, poverty alleviation and support to marine ecosystems. Further, with collaborative input from organisations across businesses, academia and government, the vision of an up-scaled, responsible and restorative macroalgal industry is articulated, highlighting the continued need for global collaborative research on macroalgal biomass utilisation. A recent study also emphasised the potential of the European macroalgae industry's contribution towards the EU's Bioeconomy Strategy aims, as macroalgae production is currently being developed in 13 European countries with France, Ireland and Spain representing the top three countries with the highest macroalgae production units [18]. In order to witness the sustainable growth of this sector in Europe nevertheless, successful up-scaling of production volumes alongside technological and market developments still require addressing.

A number of recent reviews have addressed some of the aspects described in the current work (Table 1).

For example, Rajak et al. [19] and Torres et al. [20] reviewed the processes involved in bioethanol, value added products and chemicals production from seaweed feedstocks, while Filote et al. [21] focussed on non-bioenergy products and advances in metabolite and bioactive molecule separation. Jung et al. [22] highlighted the importance of 
Table 1

Recently published review articles on seaweed biorefineries relevant to the current review article.

\begin{tabular}{|c|c|c|}
\hline Review article title & Key features of review article & Reference \\
\hline $\begin{array}{l}\text { A holistic zero waste } \\
\text { biorefinery approach for } \\
\text { macroalgal utilisation: A } \\
\text { review }\end{array}$ & $\begin{array}{l}\text { - Global seaweed production, } \\
\text { cultivation and harvesting } \\
\text { - Seaweed hydrolysis for } \\
\text { fermentable sugars production } \\
\text { - Fermentation and seaweed } \\
\text { bioethanol production } \\
\text { - Value added products from } \\
\text { fermented residual biomass } \\
\text { - Challenges for seaweed biofuel } \\
\text { production }\end{array}$ & [19] \\
\hline Seaweed biorefinery & $\begin{array}{l}\text { - Seaweed composition, properties } \\
\text { and uses } \\
\text { - Seaweed biorefineries and } \\
\text { bioproduct/biofuel production } \\
\text { - Challenges and constraints } \\
\text { associated with seaweed } \\
\text { biorefineries }\end{array}$ & {$[20]$} \\
\hline $\begin{array}{l}\text { Biorefinery of marine } \\
\text { macroalgae into high-tech } \\
\text { bioproducts: a review }\end{array}$ & $\begin{array}{l}\text { - Wild and cultivated seaweed } \\
\text { resources for biorefinery } \\
\text { applications } \\
\text { - Chemical composition of seaweed } \\
\text { - Advances in metabolite and } \\
\text { bioactive molecule separation, } \\
\text { including novel extraction } \\
\text { methods and biorefinery } \\
\text { approaches }\end{array}$ & {$[21]$} \\
\hline $\begin{array}{l}\text { Potential of macroalgae as } \\
\text { feedstocks for biorefinery }\end{array}$ & $\begin{array}{l}\text { - Mass cultivation of seaweed } \\
\text { - Biomaterials, bioproducts and } \\
\text { bioenergy production from } \\
\text { seaweed species } \\
\text { - Advanced technologies for biofuel } \\
\text { production from seaweeds, mainly } \\
\text { seaweed-specific enzyme produc- } \\
\text { tion for polysaccharide hydrolysis }\end{array}$ & {$[22]$} \\
\hline $\begin{array}{l}\text { Green technology in green } \\
\text { macroalgal biorefineries }\end{array}$ & $\begin{array}{l}\text { - Cultivation of seaweed } \\
\text { - Green seaweed derived } \\
\text { bioproducts, biomaterials, } \\
\text { biostimulants and biofuels } \\
\text { - Green cascading biorefinery } \\
\text { processes } \\
\text { - Bio and thermochemical } \\
\text { conversion processes, green } \\
\text { solvents and emerging 'smart' } \\
\text { technologies }\end{array}$ & {$[23]$} \\
\hline $\begin{array}{l}\text { Successful approaches for a } \\
\text { red seaweed biorefinery }\end{array}$ & $\begin{array}{l}\text { - Red seaweed biorefineries } \\
\text { - Bioproducts and biofuels obtained } \\
\text { from red seaweed biorefinery } \\
\text { processes }\end{array}$ & {$[24]$} \\
\hline Current review article & $\begin{array}{l}\text { - Seaweed composition and } \\
\text { cultivation } \\
\text { - Brown, red and green seaweed } \\
\text { biorefinery concepts, including } \\
\text { novel biotechnology development } \\
\text { - Commercialised seaweed-based } \\
\text { bioproducts and markets } \\
\text { - Seaweed biorefinery funded } \\
\text { projects and intellectual property } \\
\text { (patents) } \\
\text { - Challenges and issues associated } \\
\text { with future macroalgal } \\
\text { biorefineries }\end{array}$ & - \\
\hline
\end{tabular}

identifying new ways to effectively and efficiently utilise seaweeds. In addition, Zollman et al. [23] considered advancements in technologies tailored specifically towards green species of seaweed, and Álvarez-Viñas et al. [24] focussed on cascading approaches developed for red species of seaweed. The current review provides updates on some of these areas but focusses on the novel biotechnologies that have recently been applied and the use of macroalgal bioproducts across the bioeconomy. The integration of biofuels and biochemical processing has undoubtedly led society a step closer towards the commercialisation of macroalgal biorefineries, and as such, particular attention will be devoted to explaining the important need for continued collaborative research funding in this area, and the range of exciting on-going macroalgal projects currently funded around the world. In addition, for the first time, the macroalgal biorefinery patent landscape will be explored in order to gain an understanding of the evolving growth within this important field. Lastly, the technological challenges that currently exist within macroalgal biorefineries and the future areas of research that ought to be addressed for future industrial expansion of such bioprocesses are discussed.

\section{Methodology}

An electronic literature-based search was conducted using Google Scholar (https://scholar.google.com/) to identify articles published from 1993 up until 2021 related to macroalgal based biorefinery approaches for biofuels and bioproduct generation. Keywords "macroalgae" or "seaweed" or "brown seaweed" or "red seaweed" or "green seaweed" AND "biorefinery" or "bioprocess" or "biofuels" or "bioproducts" or "biochemicals" were included. All searches were limited to studies published in the English language, since these contributed to the majority of the articles found. To compare the number of macroalgae and lignocellulosic biorefinery articles that have been published each year until 2021, a document search was conducted using Scopus ${ }^{\circledR}$ (https://www.scopus.com/search/form.uri?display=basic) using keywords "macroalgae", or "lignocellulosic" AND "biorefinery".

An advanced search using the European Patent Office's patent search database to gather information on the number of macroalgal patent documents across different biotechnological industrial market subgroups, which have been published up until 2021, was conducted. The search criteria consisted of using a set of keywords ['macroalgae' OR "seaweed"] AND " $\mathrm{X}$ ", where ' $\mathrm{X}$ ' was the class of industrial application ('food", "processing', "health", "chemical", "cosmetic', "aquaculture", "agriculture", "genes", "biofuels" and "bioremediation'). For comprehensive coverage, the searches were performed with these keywords in the patent document's title, abstract or claims. It is important to note however, that, the search results do not necessarily solely reflect granted patents; the search results also return applications that may have either been withdrawn, rejected or are pending. Further, due to varying lead times between filing a patent application and publication, it is inevitable that there may in fact be more unpublished applications that were not returned. For example, in the UK there is lead time of approximately 18 months between the filing of and publication of the patent application [25]. Nonetheless, the results provide an indication into the industrial and developmental growth of the field. To identify whether any patent documents have been registered specifically for biorefinery processes utilising macroalgae, another advanced search was conducted using keywords ['macroalgae' OR "seaweed"] AND " $\mathrm{X}$ ", where X was either "biorefinery", "bio-refinery", "bioprocess", "bio-process", "bioproducts" or "bio-products". To achieve a thorough search, the returned documents $(\mathrm{n}=772)$ were screened by eye and shortlisted to ensure that the document did indeed solely focus on a biorefinery process that yielded more than at least two bioproducts from macroalgae.

\section{Macroalgae composition}

Macroalgae are macroscopic, multicellular organisms consisting of thousands of species that are frequently grouped depending on the colour of their photosynthetic pigment and cell wall chemistry [22]. Red (Rhodophyta), green (Chlorophyta) and brown (Phaeophyta) macroalgae require different intensities of light to photosynthesise, and thus are typically found in different marine habitats and environments [26]. Table 2 summarises the main biochemical constituents of these three taxonomical groups.

The carbohydrate fraction represents the largest component of their 
Table 2

Biochemical composition and main carbohydrate compositions (based on dry weight) of the three macroalgal taxonomical groups [11,117,213].

\begin{tabular}{|c|c|c|c|}
\hline & Phaeophyta (Brown) & $\begin{array}{l}\text { Rhodophyta } \\
\text { (Red) }\end{array}$ & $\begin{array}{l}\text { Chlorophyta } \\
\text { (Green) }\end{array}$ \\
\hline \multicolumn{4}{|c|}{ Proximate composition $\%$ dry weight basis } \\
\hline Ash & $8.7-41.2$ & $2.5-25.7$ & $18.0-30.0$ \\
\hline Protein & $1.1-26.8$ & $10.2-22.7$ & $10.7-25.9$ \\
\hline Lipid & $0.6-3.4$ & $0.7-7.4$ & $1.0-3.5$ \\
\hline Carbohydrate & $33.9-76.0$ & $53.2-75.8$ & $53.0-69.9$ \\
\hline \multirow[t]{5}{*}{ Polysaccharides } & Laminarin $0.8-24$ & $\begin{array}{l}\text { Carrageenan } \\
7-12\end{array}$ & Starch 17 \\
\hline & Mannitol 5-20 & Agar 6 - 36 & $\begin{array}{l}\text { Hemicellulose } \\
20\end{array}$ \\
\hline & Alginate $10-30$ & Cellulose 7-10 & Cellulose 9 \\
\hline & Fucoidan $1-10$ & & Ulvan 25 \\
\hline & Cellulose 2-7 & & \\
\hline $\begin{array}{l}\text { Photosynthetic } \\
\text { pigment }\end{array}$ & $\begin{array}{l}\text { Chlorophyll A and C } \\
\text { Carotenoids } \\
\text { (fucoxanthin) }\end{array}$ & $\begin{array}{l}\text { Phycobilin } \\
\text { Chlorophyll A }\end{array}$ & $\begin{array}{l}\text { Chlorophyll A } \\
\text { and B } \\
\text { Carotenoids }\end{array}$ \\
\hline
\end{tabular}

biochemical composition (34-76\% dry weight (dw)), comprised of different polysaccharides that are divided into three functionally different groups: 1) structural cell wall polysaccharides, 2) intracellular mucilage polysaccharides and 3) storage polysaccharides [27]. Further, macroalgae contain a relatively high protein content with typical values varying between 10 and $30 \%(\mathrm{dw})$ [28], thus representing a complementary source of food proteins for human and animal nutrition [29, $30]$. The high ash content (5-30 \% (dw)) results from the capacity of the macroalgal species to accumulate high levels of metal ions, mostly potassium, sodium, magnesium and calcium from their aquatic environment [31-33]. Lipids on the other hand, represent less than $5 \%$ of the total dry weight [34]. Despite this low value, macroalgae are an excellent source of long chain $\omega-3$ and $\omega-6$ polyunsaturated fatty acids (PUFA) compared to land based plants [35].

The harsh marine environment macroalgae inhabit exposes them to a combination of different light and oxygen concentrations, which essentially leads to the formation of free radicals and other strong oxidizing agents [36]. Consequently, a number of polyphenolic compounds (tannins, phenolic acids) and pigments (carotenoids such as fucoxanthin) have naturally accumulated which have proved to avert free radical formation [37], which have proved to possess different biological activities, including anti-oxidant [38], anti-inflammatory [39], anti-microbial [40], anti-viral [41], anti-diabetic [42], anti-cancer [43], neuroprotective [44], hepatoprotective [45] and hypertension [46] properties.

Significant variations in composition exist between the groups of macroalgae and studies have confirmed that seasonal and environmental factors, including light intensity, water temperature and nutrient content influence their overall composition, particularly the assimilation of distinctive polysaccharides $[12,33,47,48]$. Thus, it is vital that biorefinery processes utilising macroalgae, not only account for total biomass yield and weight $(\mathrm{dw})$ availability, but also biochemical composition seasonality. This would ensure that the feedstock's target constituents of interest are at their greatest compositional yield at the time of harvest in order to propose a biorefinery approach with an integral valorisation of the raw species.

\subsection{Red macroalgae (Rhodophyta)}

Red macroalgae are composed of around 4000 different species, making them the most abundant macroalgal group, and can be extensively found in both deep cold waters or warm shallow waters [49]. Species belonging to red macroalgae typically contain high carbohydrate contents $(53-76 \%(\mathrm{dw}))$ i.e. polysaccharides such as carrageenans, agar and cellulose [50]. Carrageenans, the main component in the cell wall of Rhodophytes, are sulphated linear polysaccharides of
D-galactose and 3,6-anhydro- D-galactose [51]. Three main commercial classes of carrageenan exist ( $\kappa$-carrageenan, 1 -carrageenan and $\lambda$-carrageenan), which vary compositionally relating to the amount and position of sulphate groups; with the propensity for different carrageenan types depending on species, growth conditions and process of extraction $[52,53]$. Each form has its own unique properties and application in industry. For example, к-carrageenan (typically sourced from Kappaphycus alvarezzi) makes an extremely strong gelling agent, whereas 1-carrageenan (typically sourced from Eucheuma denticulatum) can be used to create gels with greater elasticity [53]. Agar, the main polysaccharide found in agarophytes such as those belonging to the Gracilaria and Gelidium genera, is a linear polymer with alternating 3-linked $\beta$-D-galactopyranosyl and 4-linked 3,6-anhydro- $\alpha$-galactopyranosyl units [54]. Typically, it is used as a gelling agent within the food, pharmaceutical and biotechnology industries due to its gel forming abilities in aqueous environments [55].

\subsection{Green macroalgae (Chlorophyta)}

Approximately 1500 different species of green macroalgae can be found in coastal waters with shallow tides, such as in bays, estuaries or tide pool zones [49]. Species belonging to the Ulva, Codium and Halimeda genera are representative of the main green macroalgal groups [56] and contain carotenoids and chlorophylls A and B, as their main photosynthetic pigments [22]. Green macroalgae also contain relatively high levels of carbohydrates $(53-70 \% \mathrm{dw})$ that include cellulose and hemicellulose, but are mainly represented by the complex sulphated hetero-polysaccharide ulvan that is typically found in the cell walls of Chlorophyta [57]. Ulvan is built on repeating disaccharide unit sequences composed of sulphated rhamnose and glucuronic acid, iduronic acid or xylose [58]. Although the polysaccharide displays numerous physico-chemical and biological features of interest for applications across the pharmaceutical [59,60] and agricultural industries [61], there is a lack of commercial utilisation at present due to its poor gelling properties; ulvan solutions exhibit low viscosities and demonstrate a viscosity decrease with increasing shear rate (pseudoplastic behaviour) [62].

\subsection{Brown macroalgae (Phaeophyta)}

Brown macroalgae, which include species belonging to the Fucus, Laminaria, Himanthalia, Undaria, Alaria and Ascophyllum genera, make up a total of around 1500 different species [49], and preferably grow in colder and/or shallow waters [56]. The biochemical composition of brown species of macroalgae is highly complex, and possess a unique yet heterogeneous carbohydrate composition present in high concentrations (34-76\% dw) [63]. One of the main structural polysaccharides found in Phaeophyta spp, is alginate (also known as algin or alginic acid) [64], an unbranched polymer consisting of 1,4-linked $\beta$-D-mannuronic acid (M) and $\alpha$-L-guluronic acid (G) [65]. A regular repeating pattern is absent in this polysaccharide as the alginate polymer is composed of homopolymorphic $\mathrm{M}$ or $\mathrm{G}$ regions, interspersed with heteropolymorphic $\mathrm{M}$ and $G$ regions [64]. Fucoidans, another cell wall polysaccharide suggested to have a protective role against drying [66], is composed of sulphated esters of L-fucose [67] that may also contain other monosaccharides such as xylose, galactose and mannose depending on the species, along with some proteins [68]. Interest in fucoidans has significantly increased due to the range of biological activities the polysaccharide has been shown to exhibit, including antioxidant [69], antiviral [70], anti-inflammatory [71] and antitumor [72] effects, that are directly related to its structure, composition, sulphate content, position of sulphate ester group and molecular weight [73]. Laminarin, a storage glucan typically used as a food reserve in Phaeophyta, is found in cell vacuoles and consists of a linear polysaccharide of $\beta$-(1-3)-D-glucose with terminating chains of D-mannitol and occasional $\beta-(1-6)$-glycosidic linkages [74]. The structural features of laminarin vary according to 
species with respect to the M:G and degrees of polymerisation, which are believed to influence its biological activities [75] including anti-tumour and wound-healing activities [76].

\subsection{The importance of understanding macroalgal cell wall structure}

The majority of lignocellulosic plant cell walls consist of large, complex and rigid biopolymers such as cellulose, hemicellulose, lignin and pectin [77]. The interconnected structure of plant cell walls has been extensively studied and is well understood. In contrast, macroalgal cell walls are chemically and structurally more complex and heterogeneous compared to terrestrial land plants, and existing methodologies developed for lignocellulosic cell wall characterisation are not compatible.

Deciphering the structural composition and architecture of macroalgal cell walls is a challenging task and, due to the fact that macroalgae are a polyphyletic group [78], attempts to accurately depict the variations in structure is hindered by the dynamic chemical diversity that exists between Rhodophyta, Chlorophyta and Phaeophyta. To date, structural models of macroalgal cell walls are generalisations of how polysaccharides and proteins are organised and interlinked [79] as depicted in Fig. 2.

Macroalgal cell walls typically consist of a fibrillar skeleton material, usually cellulose, yet can be replaced by xylan and mannan according to taxonomical group, and an amorphous embedded matrix also containing polysaccharides unique to each taxa [80]. Red macroalgal cell walls
(Fig. 2 A) generally consist of cellulose microfibrils and a family of hydrocolloids made up of sulphated glucans, such as carrageenans and agars, more complex xylogalactans and glucomannans [81]. Green macroalgae (Fig. 2 B) also contain a cellulose fibrillar material, which may have fibrillary components including $\beta$-D-xyloglucans and mannans that replace cellulose [82]. However, these skeletal polysaccharides form double fibrillar layers (inner and outer layers), with an amorphous matrix in between mainly comprising of sulphated polysaccharides such as ulvan and glucuronan layers [83]. Brown macroalgal cell walls (Fig. 2C) additionally consist of a fibrillar framework of cellulose microfibrils that are present in layers which are parallel to the cell surface, but with no clear orientation [82]. Alginate polysaccharides are enmeshed within the cellulose layers, but also reside within the interfibrillar matrix alongside fucose containing sulphated polysaccharides, proteins and phenols [84]. Clearly, the majority of macroalgal bioproducts, including polysaccharides, are either stored within the cell wall, or are bound to cell membranes, which ultimately need to be disrupted prior to extraction.

An additional barrier also exists with macroalgae, the macrostructure, which also requires disruption to gain access to the internal cell wall and cell membrane [85]. A greater structural understanding of cells walls belonging to the most promising macroalgal species (across all taxonomical groups) that will be used as feedstock for future biorefineries require attention at this present time. This underlying knowledge will assist in optimising biorefinery development and efficient deconstruction of this unique feedstock.

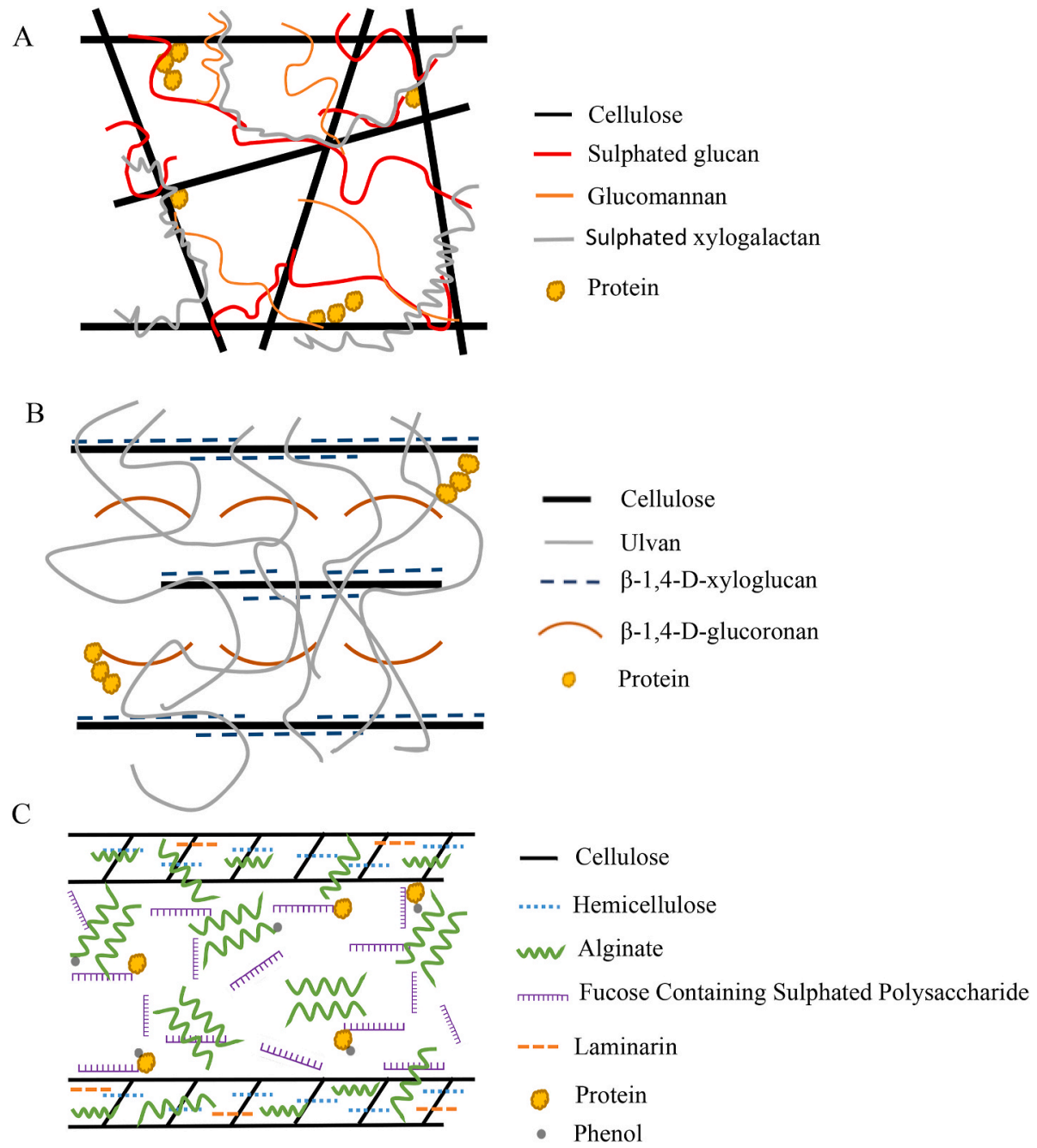

Fig. 2. Schematic generalisations of cell wall models belonging to A) red, B) green and C) brown macroalgae (Adapted from: [79,83,221-224]). 


\section{Current status of macroalgal production and cultivation}

The macroalgae aquaculture sector continues to grow in both size and value on an annual basis, with Food and Agriculture Organisation of the United Nations (FAO) data stating that global macroalgal aquaculture production in 2016 equated to ca. $30 \mathrm{~m}$ tonnes at a value worth USD11.6 bn [86]. The largest global producer of macroalgae is Asia, with China leading production volumes of $14 \mathrm{~m}$ tonnes valued at USD8.6 bn, followed by Africa with a production volume of around 140,000 tonnes and the Americas with 15,634 tonnes [86]. In Asia, mass cultivation technologies have already been established for a number of different macroalgal species, including Laminaria japonica, Eucheuma spp., Kappaphycus alverezii, Pyropia yezoensis, Undaria pinnatifida and Graciliaria verrucosea [22]. Europe, on the contrary, still has a relatively small aquaculture industry, and cultivation technologies are lagging in comparison. Nevertheless, the drive to stimulate the European macroalgae market and aquaculture sector is at a much earlier stage, and both academic and business-related interests have propelled strategies to cultivate macroalgae on a larger scale. This is evident by the increasing number of European research projects focussing on the development of macroalgal cultivation techniques, biorefinery processes and the production of marketable macroalgal-based products (discussed further in Section 6). Furthermore, EU and national policy initiatives have led to the establishment of macroalgal farms in Dutch, Norwegian, Portuguese and Irish waters, with the aim of producing commercial species of macroalgae (such as Saccharina spp., Alaria spp. and Ulva spp.) and macroalgal based products [87].

Cultivation is an extremely important aspect, which needs to be supported and integrated, for the development of large-scale sustainable macroalgal biorefineries. For such biorefineries to flourish sustainably and economically, the process cannot be reliant upon the wild-stock harvesting of species, or on the cultivation of on-shore or near shore farms $[88,89]$. Wild-harvesting will inevitably lead to over-exploitation, whilst on-shore and near-shore cultivation could compete with coastal uses (such as fishing) and food-crops. The implementation of large-scale off-shore cultivation systems have been proposed to be the most promising alternative able to withstand the challenges associated with the aforementioned systems, particularly if coupled with integrated multi-trophic aquaculture systems (IMTA) and wind energy production [90,91].

The constant supply and high-volume production of a suitable species of macroalgae as feedstock underpins biorefinery development. However, one of the main hindrances associated with biorefinery development remains the macroalgal cultivation part itself. Life cycle analyses (LCA) and techno-economic assessments (TEA) of such processes have often highlighted that the cultivation phase of the system is the most costly and energy intensive, and advancements in research and development are needed here in order to make macroalgal biorefineries economically viable [92]. Improvements in the understanding and knowledge of macroalgal life cycles, as well as the design of new optimal and compatible cultivations systems (mainly for offshore cultivation) for each species of macroalgae are vital for successful development. Furthermore, the energy balance or energy return of the process are also required for each species. This includes decreasing operational and capital costs (such as labour costs, technology and energy inputs) whilst simultaneously improving and increasing biomass yields and the value of prospective bioproducts [93]. Although the prospects of offshore cultivation will propel the bioeconomy of any country through job and wealth creation for coastal communities, including the societal acknowledgement of macroalgae as a biorenewable feedstock, the economic feasibility of macroalgal cultivation will undoubtedly differ between global regions. For example, labour and materials costs are more expensive in Europe compared to Asia and South America, and therefore will require more technological advances to compensate. A number of excellent reviews regarding the topic of macroalgal cultivation and large-scale farming have been published, of which the authors recommend the following articles for a more in-depth evaluation on this topic: [94-98].

\section{The macroalgal biorefinery concept}

Implementation of a biorefinery that follows a holistic zero waste approach is a fundamental requirement to comply with the key principals of the EC bioeconomy framework [99]. There is an imminent need to reduce waste and maximise the economics of a bioprocess, by generating multiple products from the same biomass via the implementation of sustainable biotechnologies. General bioprocess design principles would suggest that bioproducts of higher value should be recovered first followed by lower value products. This essentially translates to the extraction of bioactive and functional based compounds, sugars and minerals. Subsequently all the remaining residue needs to be used as a feedstock for biofuel or platform chemicals production to avoid waste generation [100].

Even though macroalgae contain a plethora of untapped biochemical constituents, numerous challenges still need to be overcome to facilitate the fruition of macroalgal biorefineries. These include the identification of the range of high value bioproducts (i.e. quantities and values) that can be acquired from different macroalgal feedstocks and, importantly, the technological and economic feasibility of the bioprocess and cascading approach which has been employed [101]. In recent years nonetheless, researchers have understood the imminent need to move away from feedstock programmes that focus on single-based product objectives and have started to explore multiple cascading approaches to biorefine different species of macroalgae for multiple bioproduct generation. An example of a macroalgal biorefinery flowchart is illustrated in Fig. 3. This depicts both upstream and downstream processing sections in addition to the numerous biotechnological processing routes that may be employed for feedstock valorisation.

The most suitable bioprocessing route for a particular product(s) will ultimately depend on the species of macroalgae used as feedstock and its susceptibility to the bioprocess technology used. It is also vital to recognise that, for macroalgal biomass in particular, upstream bioprocessing may significantly determine the range of downstream endproducts; the biochemical composition of macroalgae can be significantly influenced by a range of cultivation parameters [102]. Furthermore, depending upon the targeted bioproduct of interest, selection of the most ideal approach or combination of approaches are paramount. A typical example of this is for bioethanol production [103]. This involves either physical, chemical and biological (or a combination of both) pretreatments which serve to expose the feedstock's cell wall constituents, followed by the subsequent enzymatic hydrolysis of polysaccharides into their respective monomeric constituents [104,105]. The vital pretreatment/s stage is used to enhance the liberated sugar yields that are achieved through enzymatic hydrolysis, for fermentation of liberated sugars into bioethanol, Nonetheless, the biochemical composition and structure of cell walls in seaweeds significantly differ from the complex lignocellulosic structures of plant-based materials, that have traditionally been utilised for the production of bioethanol [106]. As such, less labour intensive and costly pretreatments can, in theory, be applied to seaweeds. However, identification of the most ideal pretreatment/s and bioprocessing route, tailored towards seaweeds, need investigation particularly in biorefinery processes where bioethanol/biofuel production take centre stage.

The formulation of detailed and preferably optimised, speciesspecific macroalgal biorefinery roadmaps, which link both upstream and downstream bioprocessing should become focus of the academic research community, with the specific aim of cataloguing the range of potential biobased products and their yields. To support this effort, the latest literature on cascading macroalgal biorefineries developed specifically for each taxonomical group are discussed in this section. The covalorisation of multiple bio-products generated from the original starting macroalgal feedstock are also examined. 


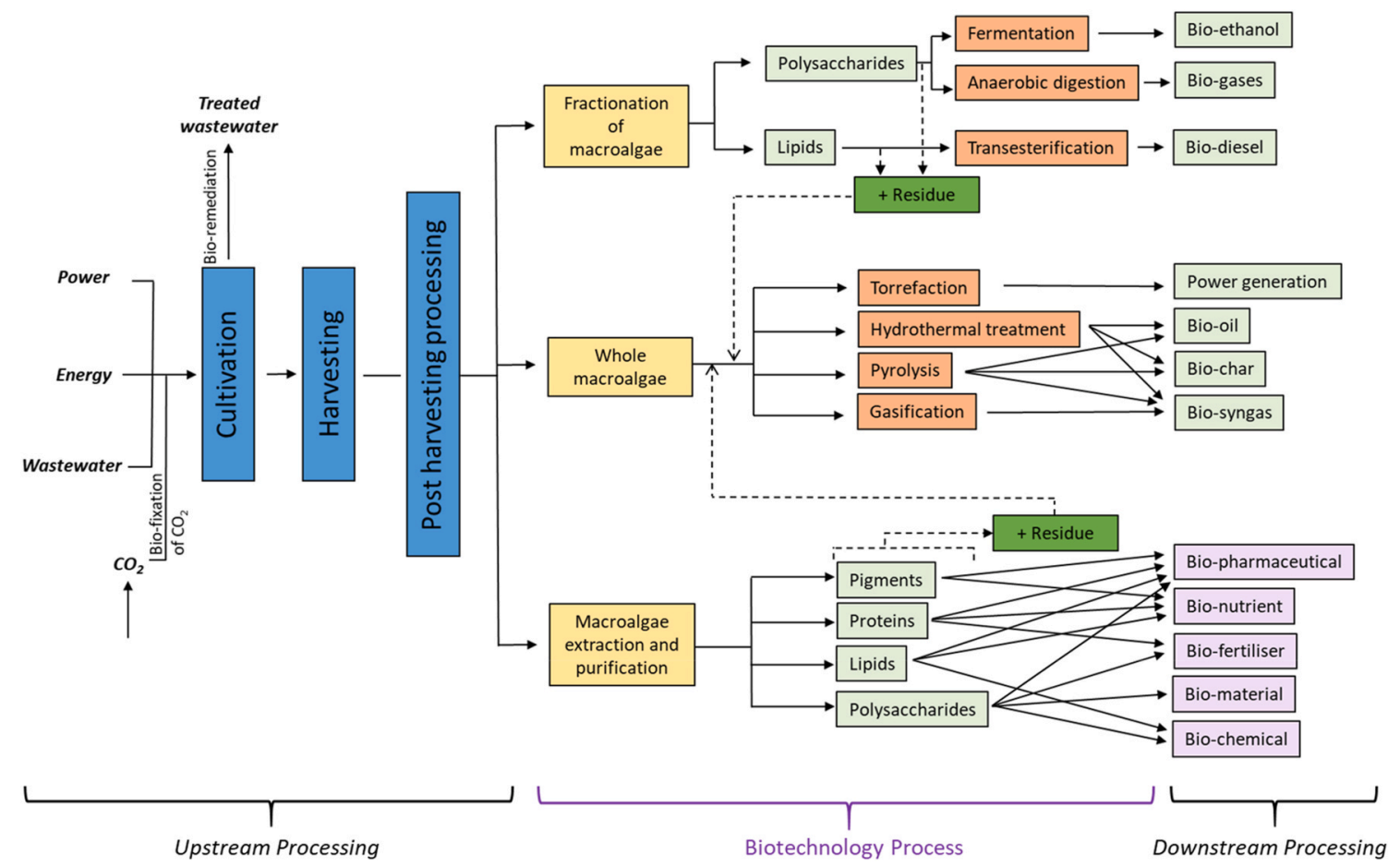

Fig. 3. Macroalgal biorefinery pathway flowchart (Adapted from Ref. [102]). Residues generated from either of the fractionation/extraction pathways ought to be compatible with subsequent physical treatment methods for energy or chemical feedstock generation.

\subsection{Red macroalgal biorefineries}

Rhodophyta, from both historical and current perspectives, are an economically relevant resource. Representing approximately $60 \%$ of the total global seaweed production [107], they are mainly processed for the extraction of agar or carrageenan, depending on species. The hydrocolloids carrageenan and agar, have frequently been the primary target for recovery during the initial stages of a bioprocesses, using mild extraction procedures in to avoid structural damage. Masarin et al. [108] and Kumar et al. [109] explored the extraction of carrageenan and agar, respectively, and assessed the suitability of the remaining residues as feedstock for bioethanol production. Masarin et al. [108] identified that $60-63.5 \%$ carrageenan can be extracted from Kappaphycus alverezii, and the glucan in the remaining residues could be targeted for glucose liberation (11.5-13.7 $\mathrm{g} \mathrm{L}^{-1}$ of glucose was successfully liberated post enzyme hydrolysis). Similarly, Kumar et al. [109] suggested that a biorefinery approach utilising Gracilaria verrucosa for the production of agar and bioethanol could be commercially viable, and yielded $0.43 \mathrm{~g}$ of bioethanol $\mathrm{g}^{-1}$ of liberated sugar from an agar-free residue. Glucose and additional monosaccharides that remain in post extraction process residues are key precursors to produce carbon-based end-point products, such as bioethanol. Additionally, alternative industrially suitable chemicals can also be recovered from macroalgal waste residues. This includes levulinic acid, a decomposition product of cellulose, which has been identified as one of twelve top value added chemicals from biomass that can serve as a platform chemical for the manufacture of polymers, pharmaceuticals, plasticisers and fuel additives [110]. A levulinic acid yield of 16 wt $\%$ was produced from the microwave pretreatment of Gracilaria lemaneiformis food waste, under the experimental conditions of $0.2 \mathrm{M} \mathrm{H}_{2} \mathrm{SO}_{4}$ for $20 \mathrm{~min}$ at $180^{\circ} \mathrm{C}$, with a biomass loading rate of $5 \%$ $(\mathrm{w} / \mathrm{v})[111]$. This process additionally generated a residual biochar that may be used a direct fuel source, particularly since higher heating values of $19-25 \mathrm{MJ} \mathrm{kg}^{-1}$ were reported.

Cascading biorefinery approaches can also be applied. Francavilla et al. [112] recovered phycobilirubens R-phycoerythrin $\left(7 \mathrm{mg} \mathrm{g}^{-1} \mathrm{dw}\right)$, allophycocyanin $\left(3.5 \mathrm{mg} \mathrm{g}^{-1} \mathrm{dw}\right)$ and phycocyanin $\left(2 \mathrm{mg} \mathrm{g}^{-1} \mathrm{dw}\right)$ from
Gracilaria gracilis, before subjecting the residue to fast pyrolysis to generate bio-oil and biochar. However, due to the high content of nitrogenous-based compounds that were present in the bio-oil the authors suggested it was unsuitable for direct use as a biofuel. The biochars generated from this study contained inorganic nutrients such as $\mathrm{P}, \mathrm{K}, \mathrm{Ca}$, $\mathrm{Fe}$ and $\mathrm{Mg}$ and were in accordance with previous studies that suggest macroalgal biochar has properties that provide soil nutrient benefits, a recurring theoretical concept which does not stand up to practical assessments [113] (see also section 5.3 below).

Trivedi et al. [114] demonstrated the feasibility of developing a sequential extraction process that recovers valuable commodity bioproducts, such as pigments, lipids, agar, minerals and cellulose, from the red species Geliedella acerosa and Gracilaria dura. The authors calculated that from 1 tonne of fresh macroalgal biomass, $0.3-0.7 \mathrm{~kg}$ of R-phycoerythrin, $0.1-0.3 \mathrm{~kg}$ of R-phycocyanin, $1.2-4.8 \mathrm{~kg}$ of lipids, $28.4-94.4 \mathrm{~kg}$ of agar and $4.4-41.9 \mathrm{~kg}$ of cellulose (from which $1.8-17.4 \mathrm{~kg}$ bioethanol is achievable) could be obtained. In another study, a similar approach was employed where integrated aqueous extraction steps were followed in order to recover a stream of similar biobased products from another red macroalgal species, Gracilaria corticata [115]. From the sequential bioprocess, R-phycoerythrin and R-phycocyanin were recovered from fresh seaweed feedstock, whilst crude lipids, agar, soil conditioner and bioethanol were generated from dried feedstock. A mineral rich liquid with potential fertilizer applications also remained. Such seaweed biorefinery approaches are attractive since the initial recovery of pigments was accomplished on wet feedstock, thus eliminating the early requirement to thermally dry the feedstock material which is often a relatively energy intensive step. Additionally, complete utilisation of the entire feedstock was achieved without the generation of any waste material, and any solvents used were recycled.

The successful reduction of waste within a biorefinery process is a desirable target that ought to be obtained, as this factor is one the key criterions embedded within the circular biorefinery concept. Offei et al. [116] accomplished this during their study which demonstrated the feasibility of generating bioelectricity from residues of macroalgae that remained post bioethanol production. The study explored this integrated 
biorefinery approach of bioethanol and bioelectricity production from three diverse species of macroalgae from the Ghanaian coast: Ulva fasciata (green), Sargassum vulgare (brown) and Hydropuntia dentata (red). Bioethanol yields of 5.1, 3.7 and $2.4 \mathrm{~g}$ per $100 \mathrm{~g}$ (of dried matter) were obtained from the respective samples, after which the residues were used as substrates in microbial fuel cells (MFC) to generate bioelectricity. The respective power densities obtained were $0.50,0.46$ and $0.48 \mathrm{~W} \mathrm{~m}^{-1}$. These values showed initial promise in what appears to be the first study at the time of writing this review, to explore macroalgal bioethanol residues as substrates in MFCs, particularly since the most efficient MFC substrate sodium acetate (control), had a power density of $0.95 \mathrm{~W} \mathrm{~m}^{-1}$.

\subsection{Green macroalgal biorefineries}

It is becoming increasingly evident that the utilisation of seaweeds belonging to the Chlorophyta are one of the most promising alternative biorefinery feedstocks. One of the earliest studies to assess the potential of generating multiple biobased products was in 2013, where van der Wal et al. [117] produced $0.35 \mathrm{~g}$ bioacetone, biobutanol and bioethanol $\mathrm{g}^{-1}$ sugar from an Ulva lactuca hydrolysate liquid fraction (generated from hot-water treatment followed by enzymatic hydrolysis) fermented with Clostridium acetobutylicum and Clostridium beijerinckii. Although these findings opened the prospects of multiple carbon-end point product generation from a single macroalgal feedstock, the recovery of additional biobased compounds of greater value than biofuels and platform biocommodity products are now generally considered to be incorporated within the bioprocess [24]. This would serve to ensure the bioeconomic stability of a biorefinery process. Nonetheless, such approaches ultimately require an in-depth understanding of the availability of such bioproducts and their potential industrial applications; and how their yields differ annually within the macroalgal feedstock itself. As such, a study by Magnusson et al. [118] calculated the productivity of bioproducts in Ulva ohnoi and Derbesia tenuissima with potential nutraceutical and cosmetic applications. Average annual biomass productivities of 56 tonnes $\mathrm{dw} \mathrm{Ha} \mathrm{Ha}^{-1} \mathrm{yr}^{-1}$ for D. tenuissima and 138 tonnes $\mathrm{dw} \mathrm{Ha}{ }^{-1} \mathrm{yr}^{-1}$ for $U$. ohnoi were achievable (under controlled land-based cultivation), and lipids ( $13 \% \mathrm{dw})$ and fatty acids ( $5 \% \mathrm{dw})$ for D. tenuissima and soluble fibres (ulvan, $12 \% \mathrm{dw}$ ) for $U$. ohnoi were calculated. Annual amino acid productivities of $U$. ohnoi and
D. tenuissima were recorded to be $18 \mathrm{Ha}^{-1} \mathrm{yr}^{-1}$ and $14 \mathrm{Ha}^{-1} \mathrm{yr}^{-1}$, respectively. Such studies are vital to gain an insight into yields and financial prospects of any potential biorefinery process, regardless of the starting macroalgal feedstock.

The application of macroalgal fractions as functional ingredients for dietary consumption has attracted significant attention in recent years, and studies have explored novel approaches in the biorefinery of green macroalgae with the inclusion of additional proprietary steps targeted at the mineral (salt) content of green macroalgae. Macroalgal salts have been considered to be associated with a healthy balance of vital minerals required for human nutrition, particularly since they contain high proportions of potassium and magnesium, with favourable sodium to potassium ratio features that can prevent hypertension and cardiovascular disease $[119,120]$. The works of one particular group have highlighted the prospects of incorporating an initial fresh water washing treatment as a first step in a cascading biorefinery for natural salt fractionation, and how subsequent residues can be valorised for additional bioproduct generation that include the polysaccharide ulvan and proteins [121-123]. This has ultimately led to culmination of multiple bioprocessing options on $U$. ohnoi, outlined in Fig. 4, which depicts the pre-defined processes and the protein enrichment processing options that were trialled on the salt and ulvan-free residue, including enzyme hydrolysis, microwave assisted extraction, a combination of both microwave assisted extraction and enzyme hydrolysis, and protein isolation. The quality of certain protein fractions, PEB-I and PI (Fig. 4) were similar to soybean meal containing 41.6 and $43.4 \mathrm{~mol} \%$ of essential amino acids, respectively, representing a potential avenue for product development. Nevertheless, it is noteworthy to mention that simpler biorefinery processes (possibly made up by two-stages) may be more suitable over a complex, multi-stage bioprocess, as the overall LCA) and TEA would be more favourable. This is certainly a factor that requires consideration when developing bioprocesses for multiple bioproduct generation; more bioprocessing steps must be implemented.

One way to enhance the LCA and TEA of a bioprocess is the adoption of 'green extraction technologies', which are particularly attractive to incorporate within cascading biorefineries due to their environmentally friendly and less hazardous status plus their ability to reduce energy consumption and promote the recovery of bioproducts of greater purity and quality [124]. Subcritical water hydrolysis treatment $\left(180^{\circ} \mathrm{C}, 10.5\right.$ bar for $40 \mathrm{~min}$ at a solids loading rate of $8 \%(\mathrm{w} / \mathrm{w}))$ using seawater, was

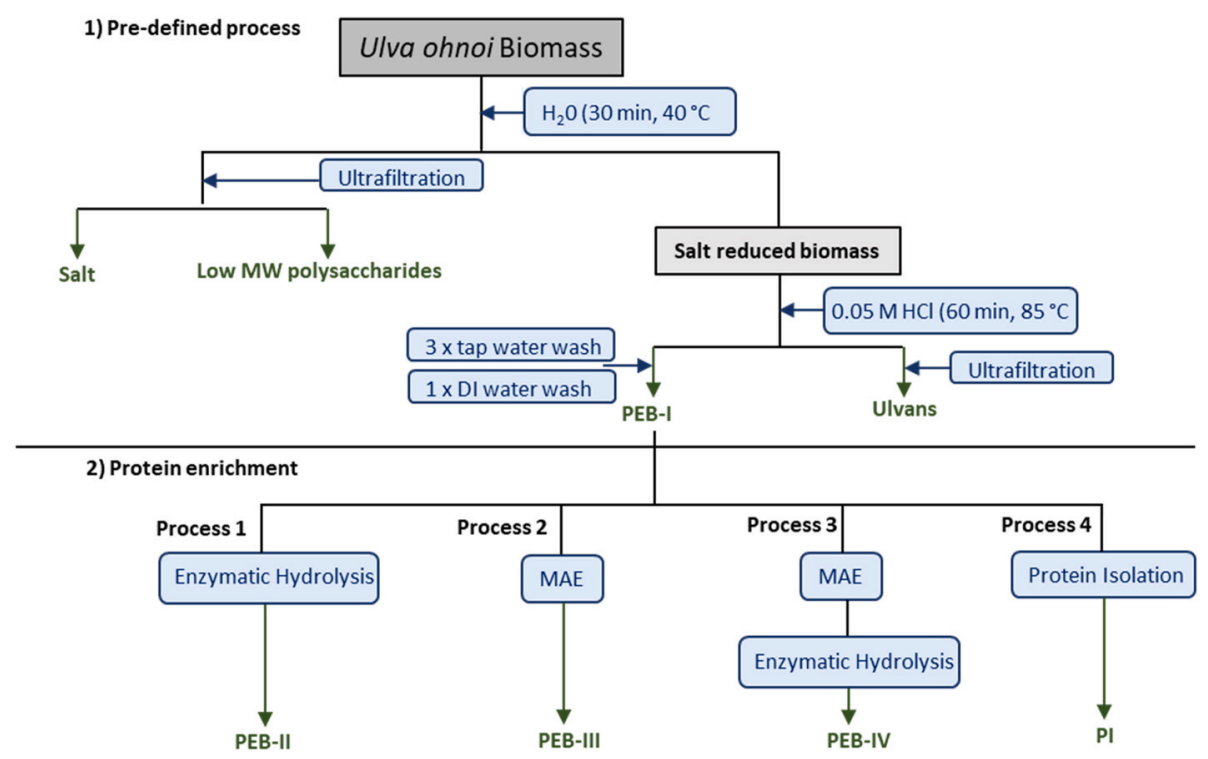

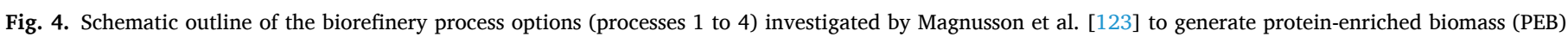

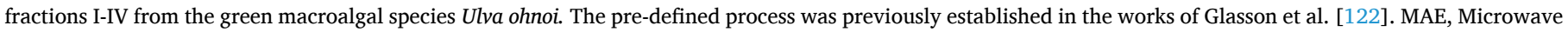
Assisted Extraction; MW, Molecular weight; DI, deionized water (milli-Q); PI, protein isolate. Figure taken from Magnusson et al. [123]. 
applied to a mixed composition of Ulva rigida and Ulva fascia in an integrated biorefinery study by Polikovsky et al. [125]. The treatment yielded multiple bioproducts that included a biochar residue and a liquid hydrolysate fraction containing a plethora of biocompounds such as $5.2 \mathrm{mg} \mathrm{HMF}, 24.1 \mathrm{mg}$ total monosaccharides, free amino acids, protein corresponding to $84.9 \%$ of the total protein, and $4.6 \mathrm{mg}$ of bioethanol ( $\mathrm{g}^{-1}$ of dried Ulva spp). Bottlenecks associated with the separation feasibility of certain key products on a commercial scale were raised, however, the use of seawater reducing the freshwater footprint opens a new pathway for the generation of multiple niche bioproducts for the bioeconomy.

In the work outlined by Prabhu et al. [101], six different bioproducts were sequentially extracted from $U$. ohnoi using a green extraction approach; a mineral salt-rich fraction ( $45.4 \% \mathrm{dw})$, a starch-rich fraction (3.7 \% dw), a lipid-rich fraction (3.8 \% dw), an ulvan-rich fraction (13.9 $\% \mathrm{dw})$, a protein-rich fraction $(14.8 \% \mathrm{dw})$ and finally a cellulose-rich fraction $(8.7 \% \mathrm{dw})$. The study recovered total extractable yields of all biobased products equating to $90.3 \% \mathrm{dw}$ of the macroalgae that was used, significantly reducing the waste potential of the biorefinery process. The generation of zero-waste is a vital factor in the development of any biorefinery process utilising any feedstock material, yet this may ultimately be influenced by the methodology and biotechnology that has been applied to recover bioproducts from the macroalgae. Postma et al. [85] identified that by using a high shear homogenisation technique on $U$. lactuca, in particular a two-phased experiment with a rotor speed of 21-11 $\mathrm{m} \mathrm{s}^{-1}$ and a fixed biomass concentration of $10.7 \mathrm{~g} \mathrm{~kg}^{-1}$, protein and carbohydrate extraction yields of 39 and $51 \%$ were obtained, respectively. Scanning electron microscopy validated that this technique 'broke' and 'emptied' individual cells from the thallus of the macroalgae, confirming call wall disintegration. Nonetheless, the authors revealed the process was relatively energy intensive $\left(\geq 11 \mathrm{kWh} \mathrm{kg} \mathrm{dw}^{-1}\right)$ compared to the energy density of the macroalgae ( $4.8 \mathrm{kWh} \mathrm{kg} \mathrm{dw}^{-1}$ ), and the technique requires further validation on a larger scale.

In addition to recovering multiple components, typically of higher added-value across a range of bio-industries, particular biochemical fractions have also been reserved for conversion into biofuel. Residues that are a prime waste-product from bioprocesses offer additional value which can support the bioeconomy. The production of biofuels such as bioethanol has been explored from $U$. fasciata residues which had already undergone a sequential bioprocess that recovered $26 \%$ mineral rich liquid extract, $3 \%$ lipid and $25 \%$ ulvan [126]. Bioethanol was produced at $0.45 \mathrm{~g} \mathrm{~g}^{-1}$ reducing sugar, highlighting the significance of utilising the remaining cellulose fraction in green macroalgal residues. Residues have also been evaluated for biomethane potential (BMP) with the aim of enhancing the repertoire of biofuels that can be generated from different species. Biomethane production was analysed on $U$. lactuca residues that had undergone both individual and sequential extraction of sap, ulvan and protein, in a study conducted by Mahtre et al. [127]. The highest biomethane yield of $408 \mathrm{~mL}$ biomethane $\mathrm{g}^{-1}$ of volatile solid was produced from residues that had undergone a sequential extraction of sap and ulvan fractions. Furthermore, research by Yahmed et al. [128] developed a bioprocess using the species Chaetomorpha linum that co-produced both bioethanol (0.093 $\mathrm{g}$ bioethanol $\mathrm{g}^{-1}$ of pre-treated macroalgae using $S$. cerevisiae) and biomethane $(0.26$ $\mathrm{L} \mathrm{g}^{-1}$ of volatile substrate). The study additionally employed the filamentous fungus Aspergillus awamori to secrete hydrolytic and proteolytic enzymes (endoglucanases, $\beta$-glucosidases, xylanases, $\beta$-xylosidases and $\alpha$-L-arabinofuranosidases) onto a $3 \% \mathrm{NaOH}$ pre-treated $C$. linum prior to biofuel production. Such an approach would undoubtedly aid to improve the overall LCA and TEA of the proposed bioprocess, as the use of expensive commercial enzymes was avoided.

\subsection{Brown macroalgal biorefineries}

Species of macroalgae belonging to the Phaeophyta have also attracted much attention, particularly since the group consist of commercially exploitable relatively large, high-alginate, rapid growth genera such as Ascophyllum, Laminaria, Macrocystis and Sargassum.

Alginate has often been the initial extract compound at the start of a Phaeophyta biorefinery process, employing milder treatment conditions in order to avoid thermal degradation that may lead to a loss of biofunctionality. Alginate-free residues from the species Sargassum muticum have subsequently undergone non-isothermal auto-hydrolysis to yield liquid fractions assessed for anti-oxidant activity in a study by González-López et al. [129]. The study also found that the antioxidant activity of the solubilised fraction decreased after auto-hydrolysis treatments greater than $190{ }^{\circ} \mathrm{C}$ were applied to the alginate-free residues. In order to enhance the number of added-value compounds that can be generated from S. muticum, Balboa et al. [130] proposed an alternative valorisation approach by applying green extraction and fractionation processes. Subcritical water, ethanol, ethylacetate and supercritical $\mathrm{CO}_{2}$ were applied, as well as employing green biotechnologies such as auto-hydrolysis and supercritical fluid extraction with $\mathrm{CO}_{2}$ to recover fucoxanthin, alginate, phlorotannin and fucoidan rich fractions with antioxidant activity. The study also found that microwave drying (two cycles at processing conditions of $400 \mathrm{~W}$ for $10 \mathrm{~s}$ followed by $200 \mathrm{~W}$ for $5 \mathrm{~s}$ ) of the initial $S$. muticum biomass was found to be the most optimal drying methodology to use, compared to oven, freeze-dying and press drying methods, with moisture reductions up to $83 \%$ being reported. The drying of biomass is a necessary pre-requisite prior to processing, yet is one of the most energy-intensive unit operations [104] and finding an ideal drying technology that is both cost-effective and compatible with any feedstock is vital. This is due to the fact that the different forms of drying may have either a beneficial or negative influence on the feedstock material, which consequently could impact on downstream processing or the availability of the target compounds of interest. For example, oven drying may be detrimental to the phenolic content and the antioxidant properties of extracts [131] whereas microwave drying, which is normally significantly faster due to the inherent volumetric heating effects, has been found to promote changes in feedstock microstructure, thus enhancing mass transfer and favouring molecular interactions between solvent and solutes during extraction [132].

Biorefinery processes utilising Phaeophyta species have also focussed on the recovery of additional polysaccharides, such as fucoidan and laminarin, alongside alginates, in order to enhance the overall LCA and TEA of the bioprocess. This was explored in the sequential yet selective extraction process developed by Abraham et al. [133] to extract polysaccharides alginate, laminarin and fucoidan from the Australian giant bull kelp Durvillaea potatorum. By employing an initial acidic extraction (optimal conditions identified as $0.05 \mathrm{M} \mathrm{HCl}$ at $60^{\circ} \mathrm{C}$ for $3 \mathrm{~h}$ ), followed by a conventional alkaline extraction step $\left(28 \% \mathrm{Na}_{2} \mathrm{CO}_{3}\right.$ at $60{ }^{\circ} \mathrm{C}$ with stirring for $2 \mathrm{~h}$ ), $43.6 \%(\mathrm{w} / \mathrm{w})$ of total polysaccharide products were recovered; fucoidan/laminarin, acidic extractable alginate and alkaline extractable alginate. The authors identified that the two alginate extracts, acidic and alkaline extracted alginate, possessed different properties including the mannuronic to guluronic acid ratio, viscosity and $\mathrm{pH}$ solubility range, which are factors that may ultimately influence the extracted alginates' industrial applications. This will influence which extraction process is employed during the biorefinery process, yet simultaneously opens the prospect of targeting multiple industries that require different biochemically structured types of alginate.

Exploration of different bioprocessing approaches on macroalgal species and their generated residues is imminent to identify compatible methodologies for implementation within a bioprocess. Furthermore, alternative compound prospecting from process liquid waste streams and residues, post initial polysaccharide recovery, has the potential to identify novel bioproducts with industrial value. Fig. 5 illustrates the development of two independent bioprocessing routes, both utilising the UK native species $L$. digitata, that can be interlinked as a result of the suitability and compatibility of the biochemical processing technologies employed. 


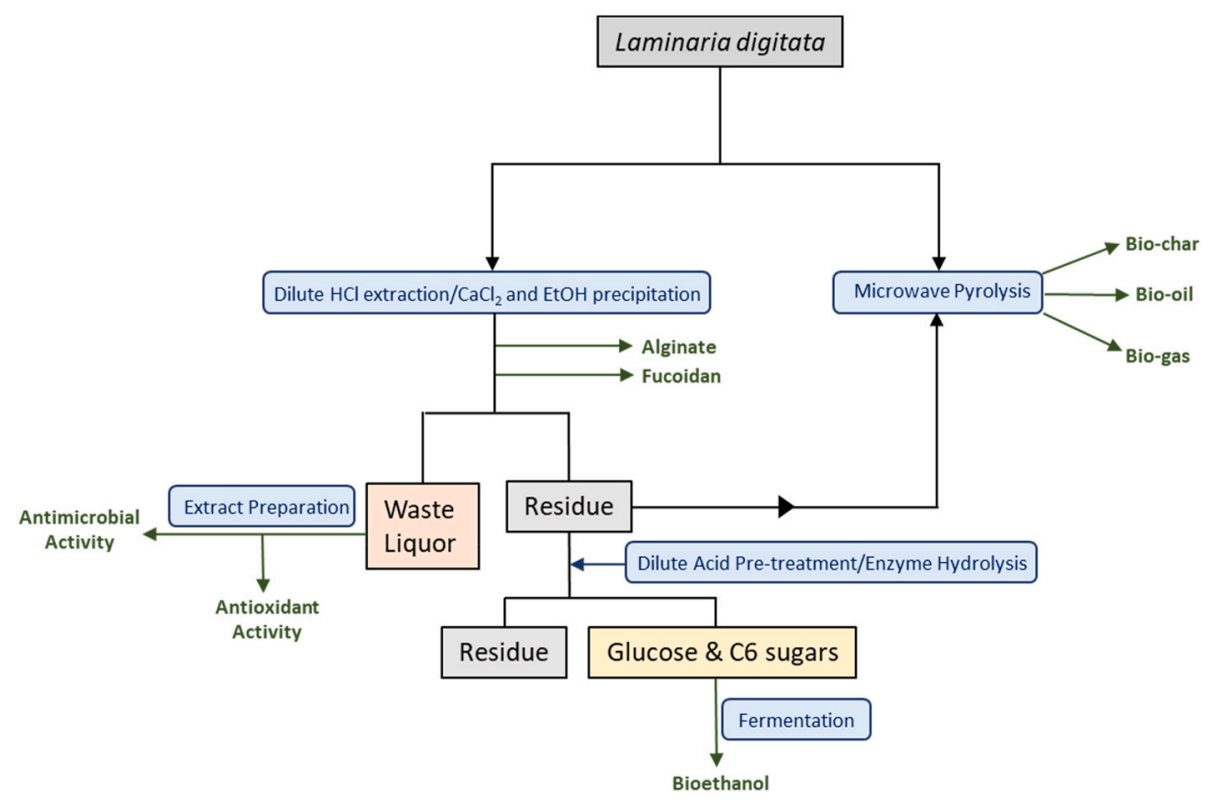

Fig. 5. Schematic diagram of the biorefining processes for Laminaria digitata for the extraction of value added compounds, bioethanol, waste streams with bioactivity, and the production of microwave pyrolysis bioproducts i.e. biochar, biogas and bio-oil [134,135].

The overall bioprocess, developed in the works of Kostas et al. [134, 135], recovered polysaccharides alginate and fucoidan, then identified the post extraction liquor waste-stream possessed antioxidant activity (EC $5015.3 \mathrm{mg} \mathrm{mL}^{-1}$ ) and anti-microbial activity against the human bacterial pathogen Burkholderia cenocepacia. The remaining solid residue was converted to bioethanol (via enzyme hydrolysis and fermentation with S. cerevisiae NCYC2592) and to bio-oil and biochar (via microwave pyrolysis). Although both studies were not fully optimised, potential routes that are compatible with $L$. digitata and its residue were highlighted in addition to the promising incorporation of microwave pyrolysis within the biorefinery paradigm to cover the range of alternative products and value-added compounds that can be obtained. Such research is imperative, in order for future biorefinery processes using different species of macroalgae and processing technologies to come to fruition.

Another thermochemical technology that has proved to be promising for inclusion within a macroalgal biorefinery is hydrothermal liquefaction (HTL). The process utilises water at sub to near critical conditions $\left(200-380{ }^{\circ} \mathrm{C}\right)$ which thus acts as both a solvent and a reactant, converting the treated biomass into biocrude oil, solid biochar and biogas as well as generating a nutrient-rich aqueous phase [136]. HTL has been suggested to be ideal for wet biomass feedstocks, avoiding the necessary prerequisite and energy intensive step of feedstock drying, making freshly harvested macroalgae a suitable candidate for this particular processing technology. Work carried out by Raikova et al. [137] screened a number of common macroalgal species, across the three taxonomical groups with the majority in the Phaeophyta, from the UK South-West coastline for their potential to produce both biocrude and nutrients that can partition into aqueous phases from a HTL process. Previously optimised HTL processing conditions $\left(345{ }^{\circ} \mathrm{C}\right.$; at a heating rate of $30{ }^{\circ} \mathrm{C} \mathrm{min}^{-1}$ ) for biocrude and nutrient recovery on Ascophyllum nodosum were applied. Under HTL processing conditions of $345^{\circ} \mathrm{C}$; at a heating rate of $30^{\circ} \mathrm{C} \mathrm{min}^{-1}$, the brown species of macroalgae generated greater biocrude yields (12-16\% dw biocrude) than the red macroalgal species which were investigated (6-8 \% dw biocrude). However, biocrude yields generated from green macroalgae, namely Ulva spp., outperformed the brown species and produced between 29 and $30 \% \mathrm{dw}$. A high concentration of ammonia, $224 \mathrm{mg} \mathrm{kg}^{-1}$, was identified in the aqueous phase produced from the HTL of L. digitata, and the highest phosphate concentrations ( $>100 \mathrm{mg} \mathrm{kg}^{-1}$ ) were identified for Fucus ceranoides and Pelvetia canaliculata. These results are relatively promising, as such concentrations are comparable to the levels found in microalgal growth media; and the aqueous phases generated from the HTL of these brown species of macroalgae could possibly be used as growth supplements for either micro or macroalgal cultivation, or even terrestrial crops.

Fig. 6 highlights prospective applications of brown macroalgal biorefinery process waste streams that have been explored, which include applications such as aquaculture diet replacements or supplements, heavy metal biosorbents and soil amendment agents.

Due to the economic and technical constraints associated with generating a suitable feed for aquaculture, these feed supplements traditionally consist of microalgae or concentrated preparations of preserved non-viable microalgae, yeast or bacteria and insect larvae or juveniles [138]. Schiener et al. [139] on the contrary, developed a suitable microalgae substitute meal from residues which remained following the enzymatic hydrolysis and bioethanol production of Saccharina latissima and Alaria esculenta; an inexpensive material that can be produced at large scale. Waste residues generated from a Fucus spiralis biorefinery process proved to successfully act as heavy metal bio-sorbents, as a study by Filote et al. [140] proved that $F$. spiralis waste, generated from a bioprocess that sequentially recovered polyphenols, fucoidan and alginate, removed $100 \% \mathrm{~Pb}$ (II) from an aqueous solution at a dosage of $0.5 \mathrm{~g} \mathrm{~L}^{-1}$. The authors additionally proposed a

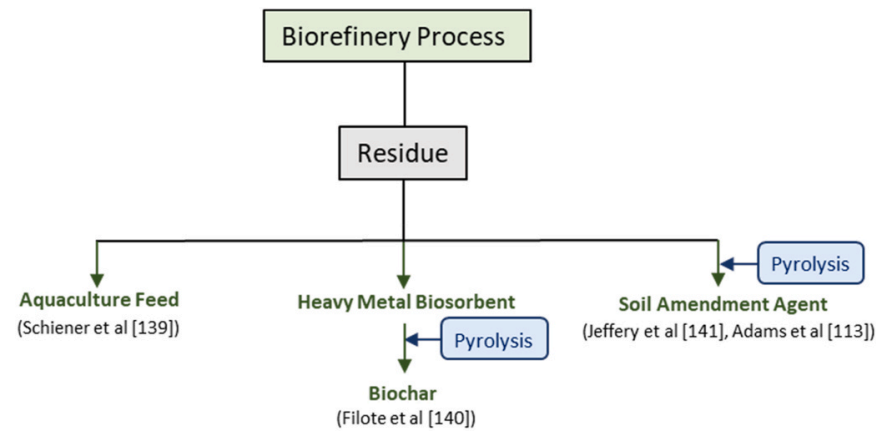

Fig. 6. Applications of waste residues generated from brown macroalgal biorefinery processes, including aquaculture feed [139], heavy metal biosorbents [140] and soil amendment agents (Jeffery et al. [141] Adams et al. [113]). 
potential final step that converts the remaining post-desorption macroalgal waste into biochar. Although macroalgal-derived biochars have often been proposed as agricultural soil amendment agents that can improve crop yields, enhance the soil carbon pool and increase rhizosphere microbial diversity [141], a study reported by Adams et al. [113] proved that pyrolysed Phaeophyta macroalgal biochars do not necessarily validate this assumption. The authors identified, in one of the first pyrolysed macroalgae char plant trials, that pyrolysed biochars (from initially ensiled $L$. digitata, L. hyperborea and S. latissima), applied at $2 \%$ $(\mathrm{w} / \mathrm{w})$ to soil, prolonged germination in germinating lettuce seeds and inhibited growth in transplanted ryegrass seedlings. It is vital that similar concepts, which are often proposed hypothetical solutions for bioprocess generated residues, are accurately trialled and validated in similar studies. This would ensure that biorefineries which truly fulfil zero-waste circular bioeconomy concepts for all brown macroalgal species, are achievable.

\section{Commercialisation of macroalgal biobased products and markets}

The emergence of the putative macroalgal biorefineries detailed above have clearly highlighted the prospects of generating novel compounds from macroalgae, with various macroalgal biochemical constituents already having known industrial value. Notwithstanding the fact that these bioprocesses are still under development, the generation of such biobased products offer significant opportunity for commercialisation and market distribution. This section details the industrial applications and uses of attainable biorefinery products and their potential role within the blue bioeconomy.

Macroalgal polysaccharides have been used across multiple industries including food and textile due to their hydrocolloidal and stabilising properties [142], as well as the pharmaceutical, medical, therapeutic, nano-medical and biological industries due to their broad range of biological activities [143,144]. These include anti-oxidant [145], anti-inflammatory [146], anti-coagulant [147], anti-proliferative effects on cancer [148] and anti-viral, anti-bacterial and anti-protozoan properties [149]. An increase in research has proved the successful application of macroalgal polysaccharides, particularly agarose, alginate, $\kappa$-carrageenan and ulvan, in the field of regenerative medicine, which includes tissue engineering [150-160]. Research is required to understand the structural and biological function of the natural extracellular milieu which is responsible for directing cell fate, and therefore, by gaining knowledge on the mechanisms behind cell function, responses to matrix development and tissue growth is imminent for advances in regenerating damaged biological components [161]. Macroalgal polysaccharides have the ability to form hydrogels that can mimic the native extracellular matrix, which is itself hydrogel-like in structure [162], and have been proposed as ideal biomaterials for regeneration strategies with varying properties and compositions. In particular, macroalgal polysaccharides have shown promise in cartilage tissue engineering applications [163] and cartilage repair [164], due to their structural and chemical similarity with native tissue components, non-harsh processing, and variable degrees of hydrophilicity and bio-compatibility [165]. An in-depth review by Bilal and Iqbal [166] discusses further biomedical applications of macroalgal polysaccharides and is highly recommended. Furthermore, the nutraceutical potential of macroalgal polysaccharides has been review by Tanna and Mishra [167].

An additional application of polysaccharides that have hydrogel forming properties, such as alginates, ulvans and carrageenans, is the production of edible films and coatings for food packaging [168]. In the presence of divalent cations, the carbohydrate groups of $\mathrm{G}$ blocks in the alginate polysaccharide backbone are able to crosslink, thus constituting an egg-box model [169] which enables the formation and subsequent commercialisation of bio-degradable and edible bio-plastics. For example, the sustainable packaging start-up company NotPla Ltd, who use alginate from brown macroalgae to create a range of bio-degradable products, including their revolutionary Ooho! flexible packaging biomaterial that can hold beverages and sauces [170]. Such biomaterials have the potential to replace single-use plastics, which can be detrimental to the environment following incorrect disposal or loss; the company are also in the process of patenting their in-house methodology for the encapsulation of liquid products into a cross-linked matrix for packaging applications [171]. Ulvan, extracted from Ulva spp., has also been trialled as a 'smart' biofilm for eco-friendly food packaging applications [172-174], however, further research is required to understand which factors (including concentration and plasticiser type) affect the properties of smart packaging films. The global market for biobased plastics was estimated to be $2.11 \mathrm{~m}$ tons in 2018 and is expected to increase to $2.62 \mathrm{~m}$ tons by 2023 [175]. Bioplastics such as polylactic acid (PLA), polyhydroxyalkanoates (PHAs) starch plastics, cellulose plastics and protein plastics, which are already commercialised and in circulation, have been the major driving force for this increase [176] and have already overcome the sustainability and waste disposal issues associated with traditional petro-chemically derived polymer plastics. Nonetheless, it is evident that hydrocolloidal polysaccharides are emerging as promising precursor candidates to aid the development of next generation bioplastics. Macroalgal polysaccharide based bioplastics have the potential to replace current bioplastics [177] particularly since not all bioplastics, such as PLA, form a closed loop cycle from 'cradle to cradle' and can decompose in all environments [178]; PLA is only compostable and not marine biodegradable unlike PHAs and hence could possibly leak into the environment [179].

Macroalgal biofuels are an additional bioproduct that have been attained from biorefinery processes, regardless of the fact that macroalgae were initially regarded as a viable feedstock solely for biofuels production. With the realisation that macroalgal biofuels production alone is not entirely economically viable and their full commercialisation is yet to be realised [95,180], their production as a secondary or tertiary product from within a biorefinery process has become more recognised. Bioethanol, biobutanol, biomethane and biodiesel are the main types of biofuels that are generally produced from macroalgae, with additional biofuels such as bio-oil, biogas and other forms of hydrocarbon derivatives being less common though continuing in research $[49,181]$. Liquid biofuels, which include bioethanol, biobutanol and biodiesel, are globally the fastest growing bioenergy sector, as an increase in government incentives attempt to incorporate such biofuels into the transportation sector in order to replace petrol and diesel [182]. In particular, bioethanol has been considered one of the most important biofuels [183]. Although a tremendous amount of research has been devoted to macroalgal bioethanol production, one of the main hindrances affecting its commercialisation is the difficulty of converting macroalgal polysaccharides and monosaccharides into bioethanol with traditional fermenting yeast and/or bacterial strains [184]. Significant research efforts have been made to generate robust strains via metabolic and bioengineering strategies that utilise the inherent macroalgal monosaccharides and yield bioethanol [185-188]. Nonetheless, a handful of putative biorefinery processes generate a cellulosic-rich residue (post the initial recovery of alternative bioproducts) which can then be hydrolysed to glucose and subsequently fermented with greater feasibility into bioethanol using conventional yeast strains [126,128, 134]. As the likelihood of generating higher yields of bioethanol from cellulose-rich waste-streams appear more promising, researchers may attempt to optimise this processing stream further particularly as the production of liquid biofuels is expected to increase to 6-8\% per year by 2050 [189] and alternative sources for achieving this target are necessary. Alternative biofuels, such as biomethane [127,128] and bio-oil [135] have additionally been explored as potential bio-fuel options from macroalgal biorefinery process waste streams, opening novel research avenues for further exploration and potential commercialisation into the energy sector.

Biochemical products such as succinic acid, lactic acid, citric acid, 
pyruvate, polyhydroxyalkanoates (PHA), chemical building blocks such as bio-butanol and isobutanol, replacement fossil-fuel derived chemicals including 2,3-Butanediol and 1,2-Propanediol, and even natural products such as pigments $[190,191]$, have been at the forefront of research with their targeted production from feedstock materials. This is associated with the fact that they comply with the U.S DoE's building block chemicals list with the specific aim to potentially overcome petro-chemically derived products. Research has shown that macroalgal biomass have successfully been utilised as feedstock to produce such desired biochemicals and biomaterials. These include the production of citric acid from Gelidiella acerosa [192], succinic acid from L. digitata [193], S. latissima [194] and Palmaria palmata [195], lactic acid from Laminaria japonica [196] and Gelidium amansii [197], 2,3-Butanediol from L. japonica [198], 1,2-Propanediol from U. lactuca [199] and poly-3-hydroxybutyrate from Laminaria sp [200]. A handful of the aforementioned biocompounds and bioproducts already have established industrial markets, with biobased levulinic acid and PHA maintaining the highest prices both valued at USD6500 per ton [201], and it is expected that other biobased products are due to also increase in the near future as long as the bioconversion technologies prove successful. Nevertheless, biobased products and biocompounds will still need to compete with the price of petro-chemically derived compounds, despite the fact that biobased products are highly likely to replace fossil-fuel derive products in the near future [202].

\section{Macroalgal funded research and intellectual property}

It is clear that recent research is enhancing the potential applications of macroalgae and the commercial viability of macroalgal biorefineries. Nonetheless, further research and developmental funding is required to ensure fruition of putative biorefinery processes into industrial reality. Although interest in macroalgae for bioenergy started to develop in the 1970s, primarily as a potential source of biofuel [95], a surge in funded research projects related to macroalgal biofuels was seen from 2010 onwards, including a number of pilot projects that focussed on the technical aspects of biofuel production from macroalgae, and also food additives and chemicals [182]. These included projects such as The SeaGas Project, MacroFuels, MacroBioCrude, and GlobalSeaweed, which have now concluded. Nonetheless, there is still a significant amount of interest, on a global scale, to continue macroalgae research and Table 3 lists the diversity of current research projects reported in the English language that are funded with a worth of $\geq £$ /USD 100,000.

As detailed in Table 3, the majority of projects are supported by government funds, such as the U.S. Department of Energy, UK Research and Innovation, the Australian Government (Department of Industry, Science, Energy and Resources), the New Zealand ministry, and the EC who have a key role in implementing EU policies. A significant number of projects funded by the U.S. Department of Energy focus on the development of cultivation systems and off-shore farms, whereas the majority of UK, European, Australian and New Zealand government funded projects focus on end product generation driven with the potential for downstream by-product commercialisation. The fact that all aspects of the macroalgal biorefinery production process, which includes cultivation, harvesting, post-harvesting processing, product recovery/generation and application, and trials of macroalgal bioproducts, are being funded will enhance research knowledge and help elucidate the realisation of macroalgal biorefineries. This is encouraging, not only because it will enable any biological and engineering challenges to be addressed, but also because issues associated with bioprocessing technologies will be highlighted as well as the sustainability and environmental issues, and bottlenecks that may impact policy and legislation.

A useful indicator to further understand the success and developmental growth of the macroalgal biotechnology sector, is the number of patents that have either been applied for, and/or granted, in the field. Patent documents, particularly granted applications, provide useful evidence of innovation, novelty, global technological development and economic benefit, regardless of the fact of whether the invention is necessarily an effective use of the resource material [203]. Fig. 7 shows the number of patent documents obtained across all the different biotechnological industrial applications related to macroalgae and seaweed.

Patents related to the food industry dominated the search, with almost 7500 patents registered, and documents associated with processing and health followed with just under 5000 documents each. This is not surprising, particularly since the links between macroalgae serving as a nutritious food ingredient and the health benefits of macroalgal extracts have been previously established through the publication of numerous research articles [204,205]. Marine aquaculture and agriculture is additionally an expanding area of research, with a significant amount of research focussing on the scalability of macroalgal cultivation and the important need for integrated multi-trophic aquaculture. Further, with the ever-increasing demand and realisation of macroalgal products and biotechnology, an increase in knowledge is required in order overcome key hindrances and challenges that are associated with macroalgal aquaculture. Even so, less than 1000 patent documents were returned for this particular search, suggesting a lower number of applications being filed compared to other industrial markets which highlights the difficulties associated with novel and innovative developments in this sector. Interestingly, the macroalgal biofuel market search only returned 40 patent documents. While biofuel production from macroalgae has been an area of research focus for a number of years, the handful of patent documents that were returned in the search uncover the fact that commercialisation of this market is relatively slow. This is mainly due to the fact that the biotechnologies and infrastructure being applied to macroalgae are most likely still not optimal for upscaling, and biofuel production as a sole process lacks viability.

A total of seven patent documents that describe bioprocesses which have yielded a number of different industrially relevant bioproducts are listed in Table 4. These include renewable and platform chemicals such as fermentation sugars, sugar acids, sugar alcohols (US9688595B2), HMF, levulinic acid and formic acid (US9452993B2), biofuels including bio-methane, bio-butanol, bio-oil (US9688595B2) and bioethanol (CN101024847, US2013005009A1), and agricultural feed and biofertiliser (US2013005009A1, CN101024847, US1000579B2). One patent in particular describes a process for the recovery of a range of diverse, industrially attractive bioproducts, which include the hydrocolloid agar, lipids, pigments and agricultural feed from the red seaweed Gracilaria corticata (US10000579B2).

The fact that only seven documents were returned could be due to a number of different factors and may not necessarily be related to a lack of research advancements in the field. It is evident from Section 5 that numerous research articles detailing the development of novel biorefinery type processes, utilising macroalgae as feedstock and yielding a plethora of desirable bioproducts and biochemicals have been published. This may be due to academics preferring to publish their findings in academic journals to disseminate and enhance the knowledge in the scientific community. Patenting is also a time consuming and costly process and there is the possibility of the patent application not being successful and the even more complicated prospect of not being able to patent the entire bioprocess, but only part of it, depending on its novelty and inventiveness. This is evident in patent US8167959B2, where the document describes the invention of a bioprocess using the kelp Macrosystis pyrifera, which has the potential to generate bioproducts with applications that include energy-saving lubricants and lubricant additives, biofuels, biochemicals, oil remediation dispersants and sorbents, non-toxic health supplications, nutraceuticals, cosmeceuticals and pharmaceutical products/ingredients, and horticultural and aquacultural feed or supplements. The broadest legal definition of the invention in the patent, however, is only directed to the algal synthetic lubricant and its associated environmentally friendly methodology of production, and does not include the other bioprocess streams and products detailed 
Table 3

Diversity of funded English-language macroalgal research projects that are currently on-going, worth $\geq £ / D 100,000$.

\begin{tabular}{|c|c|c|c|c|c|c|}
\hline Name of Project & Recipient/s & Funders & Country & Amount & Project Term & Description \\
\hline Autonomous tow vessels & $\begin{array}{l}\text { C. A. Goudey and } \\
\text { Associates }\end{array}$ & $\begin{array}{l}\text { Advanced Research } \\
\text { Projects Agency- } \\
\text { Energy } \\
\text { U.S. Department of } \\
\text { Energy }\end{array}$ & USA & USD909,901 & $\begin{array}{l}\text { April 06, } \\
2018-\text { April 05, } \\
2021\end{array}$ & $\begin{array}{l}\text { Development of an } \\
\text { autonomous marine tow vessel } \\
\text { to enable the deployment of } \\
\text { large-scale seaweed farming } \\
\text { systems. }\end{array}$ \\
\hline Ocean energy from macroalgae & Fearless Fund & $\begin{array}{l}\text { Advanced Research } \\
\text { Projects Agency- } \\
\text { Energy } \\
\text { U.S. Department of } \\
\text { Energy }\end{array}$ & USA & USD496,483 & $\begin{array}{l}\text { July 02, } \\
2018-\text { September } \\
30,2020\end{array}$ & $\begin{array}{l}\text { Novel system design and } \\
\text { development to enable large } \\
\text { scale macroalgae 'ranching' } \\
\text { using remote sensing, imaging } \\
\text { and modelling technologies. }\end{array}$ \\
\hline $\begin{array}{l}\text { Performance and impact of } \\
\text { macroalgae farming }\end{array}$ & $\begin{array}{l}\text { Macai Ocean } \\
\text { Engineering }\end{array}$ & $\begin{array}{l}\text { Advanced Research } \\
\text { Projects Agency- } \\
\text { Energy } \\
\text { U.S. Department of } \\
\text { Energy }\end{array}$ & USA & USD995,978 & $\begin{array}{l}\text { May 21, } \\
2018-\text { November } \\
20,2020\end{array}$ & $\begin{array}{l}\text { Development of tools to } \\
\text { stimulate the biological } \\
\text { performance of offshore } \\
\text { macroalgal systems. }\end{array}$ \\
\hline Biofuels from kelp & Marine Bioenergy & $\begin{array}{l}\text { Advanced Research } \\
\text { Projects Agency- } \\
\text { Energy } \\
\text { U.S. Department of } \\
\text { Energy }\end{array}$ & USA & USD2,623,787 & $\begin{array}{l}\text { June 06, } \\
\text { 2016-December } \\
31,2020\end{array}$ & $\begin{array}{l}\text { Development of an open ocean } \\
\text { cultivation system for kelp } \\
\text { biomass (with the University of } \\
\text { Southern California and } \\
\text { Wrigley Institute for } \\
\text { Environmental Studies). } \\
\text { Biomass will then be converted } \\
\text { to bio-crude (in collaboration } \\
\text { with researchers at Pacific } \\
\text { Northwest National } \\
\text { Laboratory). }\end{array}$ \\
\hline $\begin{array}{l}\text { Techniques for tropical } \\
\text { cultivation }\end{array}$ & $\begin{array}{l}\text { The Marine } \\
\text { Biological } \\
\text { Laboratory }\end{array}$ & $\begin{array}{l}\text { Advanced Research } \\
\text { Projects Agency- } \\
\text { Energy } \\
\text { U.S. Department of } \\
\text { Energy }\end{array}$ & USA & USD7,515,793 & $\begin{array}{l}\text { May 01, } \\
2018-\text { April 30, } \\
2023\end{array}$ & $\begin{array}{l}\text { Cultivation system design and } \\
\text { development for Eucheuma } \\
\text { isiforme, for biofuels } \\
\text { production. }\end{array}$ \\
\hline $\begin{array}{l}\text { Single point mooring array for } \\
\text { macroalgae }\end{array}$ & $\begin{array}{l}\text { Ocean Era (formally } \\
\text { known as Kampachi } \\
\text { Farms) }\end{array}$ & $\begin{array}{l}\text { Advanced Research } \\
\text { Projects Agency- } \\
\text { Energy } \\
\text { U.S. Department of } \\
\text { Energy }\end{array}$ & USA & USD4,249.547 & $\begin{array}{l}\text { May 10, } \\
2018-\text { April 16, } \\
2023\end{array}$ & $\begin{array}{l}\text { Design and development deep } \\
\text { seawater nutrients delivery to a } \\
\text { macroalgae production farm } \\
\text { concept, suitable for } \\
\text { deployment in tropical and } \\
\text { subtropical deep ocean } \\
\text { environments. }\end{array}$ \\
\hline $\begin{array}{l}\text { Continuous, high-yield kelp } \\
\text { production }\end{array}$ & $\begin{array}{l}\text { Trophic/Otherlab/ } \\
\text { The University of } \\
\text { New Hampshire }\end{array}$ & $\begin{array}{l}\text { Advanced Research } \\
\text { Projects Agency- } \\
\text { Energy } \\
\text { U.S. Department of } \\
\text { Energy }\end{array}$ & USA & USD5,202,016 & $\begin{array}{l}\text { March 16, } \\
\text { 2018-December } \\
04,2022\end{array}$ & $\begin{array}{l}\text { A rugged and resilient offshore } \\
\text { sea farm with high yield and } \\
\text { low capital cost will be } \\
\text { developed. }\end{array}$ \\
\hline $\begin{array}{l}\text { Scalable coastal and offshore } \\
\text { macroalgal farming }\end{array}$ & $\begin{array}{l}\text { The University of } \\
\text { Alaska Fairbanks }\end{array}$ & $\begin{array}{l}\text { Advanced Research } \\
\text { Projects Agency- } \\
\text { Energy } \\
\text { U.S. Department of } \\
\text { Energy }\end{array}$ & USA & USD3,132,133 & $\begin{array}{l}\text { April 11, } \\
2018-\text { March 01, } \\
2023\end{array}$ & $\begin{array}{l}\text { Replicable model farms capable } \\
\text { of cost-effective production of } \\
\text { sugar kelp along the Alaskan } \\
\text { coastline will be developed. }\end{array}$ \\
\hline $\begin{array}{l}\text { Macroalgae cultivation } \\
\text { modelling system }\end{array}$ & $\begin{array}{l}\text { The University of } \\
\text { California, Irvine }\end{array}$ & $\begin{array}{l}\text { Advanced Research } \\
\text { Projects Agency- } \\
\text { Energy } \\
\text { U.S. Department of } \\
\text { Energy }\end{array}$ & USA & USD1,815,529 & $\begin{array}{l}\text { May 11, 2018-May } \\
10,2021\end{array}$ & $\begin{array}{l}\text { Computational modelling } \\
\text { project that integrates an open- } \\
\text { source regional ocean model } \\
\text { with a fine-scale hydrodynamic } \\
\text { model that is capable of } \\
\text { simulating forces and nutrient } \\
\text { flows in various seaweed } \\
\text { farming systems. }\end{array}$ \\
\hline $\begin{array}{l}\text { Scalable aquaculture monitoring } \\
\text { system }\end{array}$ & $\begin{array}{l}\text { The University of } \\
\text { California, Santa } \\
\text { Barbara }\end{array}$ & $\begin{array}{l}\text { Advanced Research } \\
\text { Projects Agency- } \\
\text { Energy } \\
\text { U.S. Department of } \\
\text { Energy }\end{array}$ & USA & USD2,003,893 & $\begin{array}{l}\text { May 01, } \\
2018-\text { April 30, } \\
2021\end{array}$ & $\begin{array}{l}\text { Development of a system-level } \\
\text { solution to continuously } \\
\text { monitor all stages of seaweed } \\
\text { biomass production, providing } \\
\text { farm managers with farm data } \\
\text { products to monitor farm status } \\
\text { from outplant to harvest. }\end{array}$ \\
\hline $\begin{array}{l}\text { Modelling tool for ocean- } \\
\text { deployed farms }\end{array}$ & $\begin{array}{l}\text { The University of } \\
\text { New England }\end{array}$ & $\begin{array}{l}\text { Advanced Research } \\
\text { Projects Agency- } \\
\text { Energy } \\
\text { U.S. Department of } \\
\text { Energy }\end{array}$ & USA & USD1,323,867 & $\begin{array}{l}\text { February 06, } \\
2018-\text { February 05, } \\
2022\end{array}$ & $\begin{array}{l}\text { A high-resolution, 3D } \\
\text { computational modelling tool } \\
\text { for simulating hydrodynamic } \\
\text { forces on macroalgae } \\
\text { cultivation and harvest system } \\
\text { will be developed, to help } \\
\text { inform decisions about farm } \\
\text { structure and the requirement } \\
\text { of significant capital } \\
\text { investment. }\end{array}$ \\
\hline
\end{tabular}


Table 3 (continued)

\begin{tabular}{|c|c|c|c|c|c|c|}
\hline Name of Project & Recipient/s & Funders & Country & Amount & Project Term & Description \\
\hline & $\begin{array}{l}\text { The University of } \\
\text { Wisconsin- } \\
\text { Milwaukee }\end{array}$ & $\begin{array}{l}\text { Advanced Research } \\
\text { Projects Agency- } \\
\text { Energy } \\
\text { U.S. Department of } \\
\text { Energy }\end{array}$ & & & $\begin{array}{l}\text { March 15, } \\
2018-\text { March 31, } \\
2022\end{array}$ & $\begin{array}{l}\text { Development a breeding } \\
\text { program and to enable the } \\
\text { development of macroalgae } \\
\text { varieties that consistently } \\
\text { produce high yields under } \\
\text { farmed conditions. }\end{array}$ \\
\hline $\begin{array}{l}\text { Seaweed hatchery and selective } \\
\text { breeding technologies }\end{array}$ & $\begin{array}{l}\text { The Woods Hole } \\
\text { Oceanographic } \\
\text { Institution }\end{array}$ & $\begin{array}{l}\text { Advanced Research } \\
\text { Projects Agency- } \\
\text { Energy } \\
\text { U.S. Department of } \\
\text { Energy }\end{array}$ & USA & USD3,704,276 & $\begin{array}{l}\text { June 15, } \\
2018-\text { June 14, } \\
2021\end{array}$ & $\begin{array}{l}\text { A selective breeding program } \\
\text { for sugar kelp, Saccharina } \\
\text { latissima, will be developed } \\
\text { with the aim to improve } \\
\text { productivity and cost } \\
\text { effectiveness of seaweed } \\
\text { farming }\end{array}$ \\
\hline $\begin{array}{l}\text { Monitoring macroalgae using } \\
\text { acoustics and UUV }\end{array}$ & $\begin{array}{l}\text { The Woods Hole } \\
\text { Oceanographic } \\
\text { Institution }\end{array}$ & $\begin{array}{l}\text { Advanced Research } \\
\text { Projects Agency- } \\
\text { Energy } \\
\text { U.S. Department of } \\
\text { Energy }\end{array}$ & USA & USD2,056,621 & $\begin{array}{l}\text { February 08, } \\
2018-\text { August 07, } \\
2021\end{array}$ & $\begin{array}{l}\text { An autonomous unmanned } \\
\text { underwater vehicle (UUV) } \\
\text { system for monitoring large- } \\
\text { scale seaweed farms for } \\
\text { extended periods will be } \\
\text { developed, as a cost-efficient } \\
\text { alternative to costly human } \\
\text { labour and boat operations. }\end{array}$ \\
\hline $\begin{array}{l}\text { Teleconnected SARgassum risks } \\
\text { across the Atlantic: building } \\
\text { capacity for TRansformational } \\
\text { Adaption in the Caribbean and } \\
\text { West Africa (SARTRAC) }\end{array}$ & $\begin{array}{l}\text { University of } \\
\text { Southampton (lead } \\
\text { research } \\
\text { organisation) }\end{array}$ & $\begin{array}{l}{ }^{\mathrm{a}} \mathrm{UKRI} \\
{ }^{\mathrm{b}} \mathrm{ESRC}\end{array}$ & UK & $\begin{array}{l}£ 876,346 \\
\text { (USD1,210,263) }\end{array}$ & $\begin{array}{l}\text { Nov 2019-Oct } \\
2022\end{array}$ & $\begin{array}{l}\text { Project seeks to gain an } \\
\text { understanding for the reasons } \\
\text { behind the inundation of } \\
\text { Sargassum seaweed on the } \\
\text { beaches of the Caribbean, } \\
\text { Central America and West } \\
\text { Africa. }\end{array}$ \\
\hline $\begin{array}{l}\text { GCRF GlobalSeaweed }^{\mathrm{a}} \text { - } \\
\text { Safeguarding the future of } \\
\text { seaweed aquaculture in } \\
\text { developing countries }\end{array}$ & $\begin{array}{l}\text { Scottish Association } \\
\text { for Marine Science } \\
\text { (lead research } \\
\text { organisation) }\end{array}$ & $\begin{array}{l}\text { UKRI }{ }^{\mathrm{c}} \text { BBSRC } \\
\text { ESRC } \\
{ }^{\mathrm{d}} \text { NERC }\end{array}$ & UK & $\begin{array}{l}£ 5,419,058 \\
\text { (USD7,483,903) }\end{array}$ & $\begin{array}{l}\text { Oct } 2012-\text { Dec } \\
2021\end{array}$ & $\begin{array}{l}\text { Vision of this programme is to } \\
\text { grow the research and } \\
\text { innovation capability of } \\
\text { developing countries that are } \\
\text { engaged in seaweed farming. }\end{array}$ \\
\hline $\begin{array}{l}\text { SeaGas: Production of bio- } \\
\text { methane from seaweed by } \\
\text { Anaerobic Digestion (AD) }\end{array}$ & $\begin{array}{l}\text { Queen's University } \\
\text { of Belfast (lead } \\
\text { research } \\
\text { organisation) }\end{array}$ & $\begin{array}{l}\text { UKRI BBSRC } \\
{ }^{\mathrm{e}} \text { EPSRC }\end{array}$ & UK & $\begin{array}{l}£ 534,373 \\
\text { (USD737,987) }\end{array}$ & $\begin{array}{l}\text { July 2015-Oct } \\
2020\end{array}$ & $\begin{array}{l}\text { Project investigating the } \\
\text { replacement of grass silage in } \\
\text { anaerobic digestion with } \\
\text { seaweed. }\end{array}$ \\
\hline $\begin{array}{l}\text { Oceanium: Seaweed-based } \\
\text { compostable, marine safe bio- } \\
\text { packaging }\end{array}$ & Oceanium Ltd & $\begin{array}{l}\text { UKRI } \\
\text { Innovate UK }\end{array}$ & UK & $\begin{array}{l}£ 99,756 \\
\text { (USD137,766) }\end{array}$ & $\begin{array}{l}\text { Aug 2019-Oct } \\
2020\end{array}$ & $\begin{array}{l}\text { Project focuses on developing } \\
\text { innovative, circular life-cycle } \\
\text { bio-packaging derived from } \\
\text { sustainable sources seaweed to } \\
\text { replace single use fossil-fuel } \\
\text { based plastics to meet the } \\
\text { growing consumer, } \\
\text { government and corporate } \\
\text { demand for sustainable } \\
\text { packaging. }\end{array}$ \\
\hline $\begin{array}{l}\text { Development of the automated } \\
\text { Ooho! Machine - reducing } \\
\text { single use plastic packaging } \\
\text { for }<100 \text { mL liquids, } \\
\text { condiments and cosmetics } \\
\text { through seaweed alginate } \\
\text { membrane }\end{array}$ & $\begin{array}{l}\text { Skipping Rocks Lab } \\
\text { Limited (lead } \\
\text { participant) } \\
\text { Lucozade Ribena } \\
\text { Suntory Limited, Vita } \\
\text { Mojo International } \\
\text { Ltd (participants) }\end{array}$ & $\begin{array}{l}\text { UKRI } \\
\text { Innovate UK }\end{array}$ & UK & $\begin{array}{l}£ 343,734 \\
\text { (USD474,708) }\end{array}$ & $\begin{array}{l}\text { Feb 2019-Mar } \\
2020\end{array}$ & $\begin{array}{l}\text { The inventors have developed a } \\
\text { unique, patented, natural } \\
\text { membrane packaging derived } \\
\text { and manufactured from } \\
\text { seaweed alginate (Ooho!). This } \\
\text { project will enable the } \\
\text { developers to create an } \\
\text { automated machine to produce } \\
\text { Oohos at scale ( } 3000 \text { per day, } \\
\text { compared to the } 100 \text { per day } \\
\text { that are currently } \\
\text { manufactured using a semi- } \\
\text { manual machine). }\end{array}$ \\
\hline SeaBest (SME-Instrument) & $\begin{array}{l}\text { Seaweed Energy } \\
\text { Solutions AS }\end{array}$ & $\begin{array}{l}\text { European } \\
\text { Commission (Horizon } \\
\text { 2020) }\end{array}$ & Norway & $\begin{array}{l}€ 1,660,881 \\
\text { (USD1,963,892) (EC } \\
\text { contribution) }\end{array}$ & $\begin{array}{l}\text { Mar 2019-Feb } \\
2021\end{array}$ & $\begin{array}{l}\text { The project will launch the first } \\
\text { large-scale organic seaweed-to- } \\
\text { food cultivation and processing } \\
\text { in the EU, allowing } \\
1000-14,000 \text { tonnes of } \\
\text { seaweed to be produced in } \\
\text { Europe at up to } 56 \% \text { less cost } \\
\text { compared to current practices. }\end{array}$ \\
\hline $\begin{array}{l}\text { GENetic diversity exploitation } \\
\text { for Innovative macro-ALGal } \\
\text { biorefinery (GENIALG) }\end{array}$ & $\begin{array}{l}\text { Centre National de la } \\
\text { Recherche } \\
\text { Scientifique CNRS }\end{array}$ & $\begin{array}{l}\text { European } \\
\text { Commission (Horizon } \\
\text { 2020) }\end{array}$ & France & $\begin{array}{l}€ 10,885,817 \\
\text { (USD12,871,825) } \\
\text { (EC contribution) } \\
€ 12,224,237 \\
\text { (USD14,454,426) } \\
\text { (total budget) }\end{array}$ & $\begin{array}{l}\text { Jan } 2017-\text { Dec } \\
2020\end{array}$ & $\begin{array}{l}\text { Project consists of a consortium } \\
\text { of } 19 \text { partners from } 6 \text { different } \\
\text { countries (inclusing Seaweed } \\
\text { Energy Solutions AS).The } \\
\text { project aims to boost the Blue } \\
\text { Biotechnology Economy by } \\
\text { increasing the production and } \\
\text { sustainable exploitation of two }\end{array}$ \\
\hline
\end{tabular}


Table 3 (continued)

\begin{tabular}{|c|c|c|c|c|c|c|}
\hline Name of Project & Recipient/s & Funders & Country & Amount & Project Term & Description \\
\hline $\begin{array}{l}\text { Algae based climate feed } \\
\text { additive for methane } \\
\text { reduction in dairy cows - } \\
\text { Climate Feed }\end{array}$ & $\begin{array}{l}\text { Danish } \\
\text { Technological } \\
\text { Institute (Project } \\
\text { manager) }\end{array}$ & $\begin{array}{l}\text { Innovation Fund } \\
\text { Denmark }\end{array}$ & Denmark & $\begin{array}{l}17 \text { M DKK } \\
\text { (USD1,908,018) }\end{array}$ & 2019-2023 & $\begin{array}{l}\text { high yielding EU species of } \\
\text { seaweed: Saccharina latissima } \\
\text { and Ulva spp. } \\
\text { Develop suitable methods for } \\
\text { cultivating, harvesting and } \\
\text { processing/drying seaweed } \\
\text { into finished goods, which } \\
\text { farms can easily supplement in } \\
\text { their feed to cattle. The project } \\
\text { collaborators include Aarhus } \\
\text { University, University of } \\
\text { Waikato (New Zealand), and } \\
\text { companies Vilofoss, DLG, } \\
\text { Ocean Rainforest, Dansk Tang, } \\
\text { DryingMate, Naturmælk, and } \\
\text { SEGES. }\end{array}$ \\
\hline $\begin{array}{l}\text { University of Exeter GCRF } \\
\text { Global Research Translation } \\
\text { Award: Sustainable solutions } \\
\text { to food security challenges. }\end{array}$ & $\begin{array}{l}\text { The University of } \\
\text { Exeter }\end{array}$ & $\begin{array}{l}\text { UKRI }{ }^{\mathrm{f}} \text { GCRF } \\
\text { Newton Fund } \\
\text { Innovate UK }\end{array}$ & UK & $\begin{array}{l}£ 621,951 \\
\text { (USD858,159) }\end{array}$ & $\begin{array}{l}\text { Oct 2019-Mar } \\
2021\end{array}$ & $\begin{array}{l}\text { Strategic priority project: } \\
\text { Removal and industrial } \\
\text { conversion of Mexico's } \\
\text { problematic seaweed bloom } \\
\text { biomass into high quality, low } \\
\text { cost sustainable agricultural } \\
\text { fertiliser products, through the } \\
\text { development of a novel } \\
\text { hydrothermal processing } \\
\text { technique. }\end{array}$ \\
\hline $\begin{array}{l}\text { Marine Bioproducts and } \\
\text { Biotechnology Corporative } \\
\text { Research Centre (Bid in } \\
\text { progress) }\end{array}$ & Flinders University & $\begin{array}{l}\text { Australian } \\
\text { Government, } \\
\text { Department of } \\
\text { Industry, Science, } \\
\text { Energy and Resources } \\
\text { Cooperative Research } \\
\text { Centres program }\end{array}$ & Australia & n.a & n.a & $\begin{array}{l}\text { Flinders University leading bid } \\
\text { to establish a Marine } \\
\text { Bioproducts and Biotechnology } \\
\text { Corporative Research Centre } \\
\text { with focus on identification and } \\
\text { bioproduct development from } \\
\text { marine resources such as } \\
\text { seaweeds and microalgae. }\end{array}$ \\
\hline $\begin{array}{l}\text { Expanding Marine Biotech } \\
\text { Production \& Refinery Facility } \\
\text { to meet demand }\end{array}$ & $\begin{array}{l}\text { Venus Shell Systems } \\
\text { Pty Ltd }\end{array}$ & $\begin{array}{l}\text { Australian } \\
\text { Government, } \\
\text { Business } \\
\text { Regional Jobs and } \\
\text { Investment Package }\end{array}$ & Australia & $\begin{array}{l}\text { AUSD600,000 } \\
\text { (USD449,586) (total } \\
\text { grant amount) } \\
\text { AUSD1,326,569 } \\
\text { (USD994,011) (total } \\
\text { project value) }\end{array}$ & 2019-2022 & $\begin{array}{l}\text { Expansion of Marine Biotech } \\
\text { production and a refinery } \\
\text { facility to meet the increasing } \\
\text { demand for a range of seaweed } \\
\text { products. }\end{array}$ \\
\hline
\end{tabular}

Seaweed solutions for sustainable aquaculture

Seaweed production as a nutrient offset for Moreton Bay
Tassal Group Limited Deakin University

University of

Tasmania

Spring Bay Seafoods Pty Ltd

University of the Sunshine Coast (USC)
Australian

Government,

Department of Industry, Science,

Energy and Resources Cooperative Research Centres program

Fisheries Research and Development Corporation
Australia project value) (USD $1,385,067$ (total grant amount) AUSD5,468,110 (USD4,097,309) (total project value)

Australia AUSD370,000 (USD277,244)
Jan 2019-Jan 2022

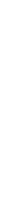

Collaborative project to develop a sustainable Integrated Multi-Trophic Aquaculture (IMTA) model that supports commercial seaweed production.

This project, in collaboration with Queensland Urban Utilities, will evaluate the nutrient offset and sequestration potential of target seaweeds in Moreton Bay, a $1500 \mathrm{~km}^{2}$ urbanised estuary, to determine the seaweed farming capacity for Moreton Bay.

Waikaitu Ltd

New Zealand Ministry of Primary Industry's (MPI)

Sustainable Food and Fibre Futures programme

Cawthron Institute New Zealand Ministry of Primary Industry's (MPI) Sustainable Food and Fibre Futures programme

$\begin{array}{lll}\text { New } & \text { NZD75,000 } & \text { June 2019-Dec } \\ \text { Zealand } & \text { (USD52,584) } & 2020\end{array}$

New Zealand

NZD100,000 (USD70,112) reduce greenhouse gas emissions
Mussel with fucoidan as supplemented superfood -
Auckland University of Technology
New Zealand Ministry of Business, Innovation and
New NZD803,000

Zealand (USD563,003)
2020-2022
Transformation of the costly mussel-industry pest seaweed species Undaria pinnatifida into a sustainable, high-value agricultural product for the global market.

Asparagopsis armata will be investigated in trials to evaluate the potential of lowering greenhouse gas emissions from cattle and livestock, and trial the production systems that are required to grow the seaweed as a feed supplement at pilotscale.

Project aims to develop a new Greenshell ${ }^{\mathrm{TM}}$ mussel Perna canaliculus as a New Zealand 
Table 3 (continued)

\begin{tabular}{|c|c|c|c|c|c|c|}
\hline Name of Project & Recipient/s & Funders & Country & Amount & Project Term & Description \\
\hline $\begin{array}{l}\text { product development and } \\
\text { clinical benefits }\end{array}$ & & $\begin{array}{l}\text { Employment } \\
\text { High-Value Nutrition } \\
\text { National Science } \\
\text { Challenge }\end{array}$ & & & & $\begin{array}{l}\text { superfood that is supplemented } \\
\text { with fucoidan extracted from } \\
\text { Undaria pinnatifida. }\end{array}$ \\
\hline $\begin{array}{l}\text { Realising the value of algae as a } \\
\text { source of alternative protein }\end{array}$ & Cawthron Institute & $\begin{array}{l}\text { New Zealand } \\
\text { Ministry of Business, } \\
\text { Innovation and } \\
\text { Employment } \\
\text { Catalyst: Strategic - } \\
\text { New Zealand - } \\
\text { Singapore Future } \\
\text { Foods Research } \\
\text { Programme }\end{array}$ & $\begin{array}{l}\text { New } \\
\text { Zealand }\end{array}$ & $\begin{array}{l}\text { NZD3,000,000 } \\
\text { (USD2,103,375) }\end{array}$ & $\begin{array}{l}\text { Oct } 2020-\text { Dec } \\
2023\end{array}$ & $\begin{array}{l}\text { In collaboration with Riddet } \\
\text { Institute, University of } \\
\text { Auckland, Plant and Food } \\
\text { Research, Singapore's Agenct } \\
\text { for Science, Technology and } \\
\text { Research, Singapore Institute of } \\
\text { Food and Biotechnology } \\
\text { Innovation and Bioprocessing } \\
\text { Technology Institute, and } \\
\text { industry partners Wakatu } \\
\text { Incorporation and Te Runanga } \\
\text { o Ngai Tahu, the project seeks } \\
\text { to investigate how the red } \\
\text { seaweed Karengo and the } \\
\text { microalga Chlorella could } \\
\text { become everyday alternative } \\
\text { sources of protein. }\end{array}$ \\
\hline
\end{tabular}

${ }^{\text {a }}$ UK Research and Innovation.

b Economic and Social Research Council.

c Biotechnology and Biological Sciences Research Council.

d Natural Environment Research Council.

e Engineering and Physical Sciences Research Council.

f Global Challenges Research Fund.

A

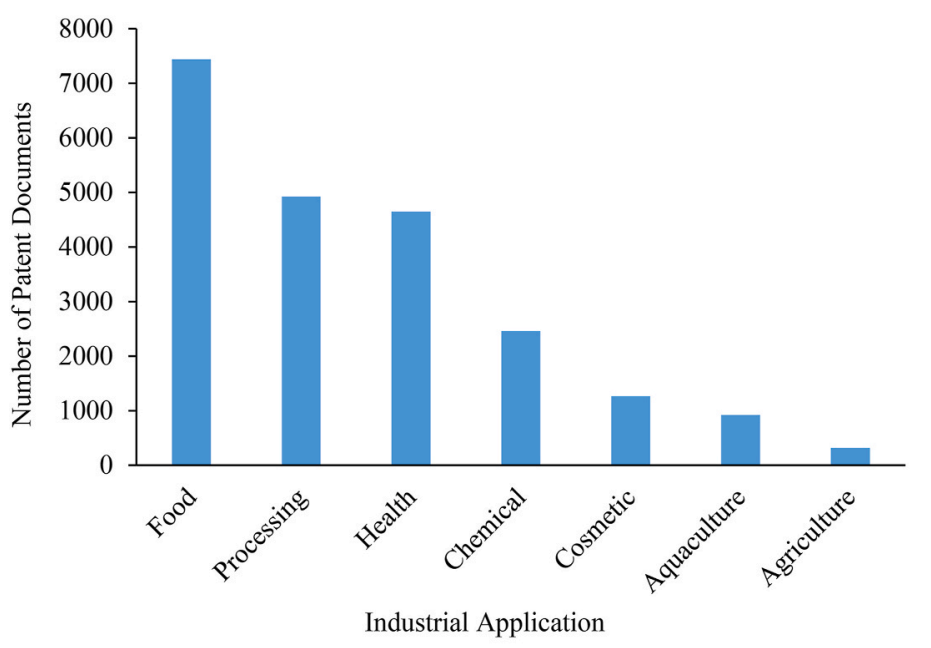

B

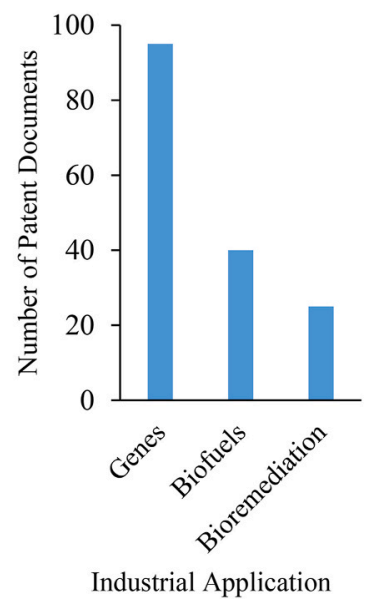

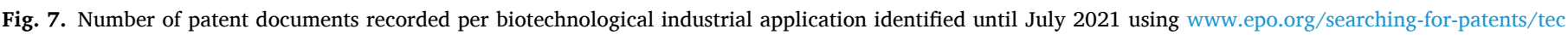
hnical/espacenet.html(Accessed 07/07/2021).

in the patent document's title and description.

Further, published research is automatically non-patentable due to public disclosure and as such, manuscripts can only be submitted for peer review after the patent application has been filed (which requires time and money). This appeared to be the case for the biorefinery process developed by Trivedi et al. [115]; a patent application was filed in 2013 (US10000579B2) and the work was subsequently published in 2016 [115]. In the current climate where one of the main assessment criteria for academic success is the output of publications, it may be possible that academics are facing with the difficult choice of either publishing research, or patenting various or entire aspects of their work.

\section{Challenges and future perspectives}

Macroalgae have been recognised as one of the most sustainable and attractive feedstocks for a transition into a blue bioeconomy, with prospects for biobased products and biofuels expanding into multiple industrial markets and sectors. Issues associated with the use of lignocellulosic feedstocks can be overcome, such as the use of large areas of agricultural land for cultivation and the requirements of lignin degradation or removal. This has enabled researchers to explore the potential of macroalgae and their incorporation into biorefinery type processes, highlighted by numerous publications and patents (seen in Sections 6 and 7). Despite this wealth of research, the growth of industrial biorefinery processes utilising macroalgae as feedstock is, and may continue to be, somewhat limited by an apparent lack of fundamental 
Table 4

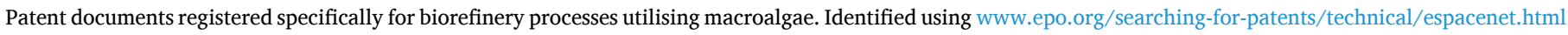
(Accessed 07/07/2021).

\begin{tabular}{|c|c|c|c|c|c|c|}
\hline Patent Number ${ }^{\mathrm{a}}$ & Title & $\begin{array}{l}\text { Year of first } \\
\text { application }\end{array}$ & Status $^{\mathrm{b}}$ & Description & Applicants & Country \\
\hline US8167959B2 & $\begin{array}{l}\text { Environmentally-friendly } \\
\text { kelp-based energy saving } \\
\text { lubricants, biofuels, and } \\
\text { other industrial products }\end{array}$ & 2009 & $\begin{array}{l}\text { Granted in the US } \\
\text { and still in force. }\end{array}$ & $\begin{array}{l}\text { Invention relates to a natural algal } \\
\text { synthetic lubricant derived from an } \\
\text { environmentally-friendly method for } \\
\text { harvesting kelp (Macrocystis pyrifera) } \\
\text { and its subsequent processing. }\end{array}$ & $\begin{array}{l}\text { Copp Emmanuel Anthony [US], } \\
\text { Glantz Dale [US], Knocean } \\
\text { Sciences, Inc. }\end{array}$ & US \\
\hline US9452993B2 & $\begin{array}{l}\text { Process for improved } \\
\text { seaweed biomass } \\
\text { conversion for fuel } \\
\text { intermediates, } \\
\text { agricultural nutrients and } \\
\text { fresh water }\end{array}$ & 2012 & $\begin{array}{l}\text { Granted in the US } \\
\text { and Australia, still } \\
\text { in application stage } \\
\text { in Japan and India. }\end{array}$ & $\begin{array}{l}\text { An integrated step-wise process for the } \\
\text { production of 5-hydroxymethlyfurfu- } \\
\text { ral (HMF), levulinic acid and formic } \\
\text { acid from } \text {-carrageenan extracted } \\
\text { from Kappaphycus alverezii. }\end{array}$ & $\begin{array}{l}\text { Council of Scientific \& } \\
\text { Industrial Research }\end{array}$ & India \\
\hline NL2019949B1 & $\begin{array}{l}\text { Improved biorefinery of } \\
\text { brown macroalgae }\end{array}$ & 2017 & $\begin{array}{l}\text { Granted in the } \\
\text { Netherlands, still in } \\
\text { application stage in } \\
\text { Australia, Canada } \\
\text { and the US. }\end{array}$ & $\begin{array}{l}\text { An improved cost-efficient and } \\
\text { durable process for biorefinery of } \\
\text { brown macroalgae (Laminaria, } \\
\text { Saccharina, Sargassum, Macrocystis, } \\
\text { Nereocystis, Lessonia, Alaria, } \\
\text { Ascophyllum and/or Fucus) which } \\
\text { comprises of an initial solvent-induced } \\
\text { dehydration step. }\end{array}$ & $\begin{array}{l}\text { TNO; Netherlands Organisation } \\
\text { for Applied Scientific Research }\end{array}$ & Netherlands \\
\hline US9688595B2 & $\begin{array}{l}\text { Process of production of } \\
\text { renewable chemicals and } \\
\text { biofuels from seaweeds. }\end{array}$ & 2011 & $\begin{array}{l}\text { Granted in China } \\
\text { and the US, still in } \\
\text { application stage in } \\
\text { Europe. }\end{array}$ & $\begin{array}{l}\text { A process for production of one or } \\
\text { more renewable chemicals } \\
\text { (fermentable sugars, sugar acids, sugar } \\
\text { alcohols) or biofuels (methane, } \\
\text { butanol, bio-oils and green crude) } \\
\text { from seaweed (Kappaphycus, Ulva, } \\
\text { Enteromorpha, Sargassum, Macrocystis). }\end{array}$ & $\begin{array}{l}\text { SEA6 Energy Private Ltd. } \\
\text { Balendiran Sowmyalashmi, } \\
\text { Kumar Sawan, Kumar, Sayash, } \\
\text { Nori Sri Sailaja, Suryanarayn } \\
\text { Shrikumar, Vadassery Nelson }\end{array}$ & India \\
\hline US10000579B2 & $\begin{array}{l}\text { An integrated process to } \\
\text { recover a spectrum of } \\
\text { bioproducts from fresh } \\
\text { seaweeds. }\end{array}$ & 2013 & $\begin{array}{l}\text { Granted in } \\
\text { Australia, Spain and } \\
\text { the US. }\end{array}$ & $\begin{array}{l}\text { An integrated process for the complete } \\
\text { utilisation of fresh seaweed biomass } \\
\text { (Gracilaria, Gelidiella, Gellidium, } \\
\text { Kappaphycus, Sarconema) to recover } \\
\text { agar, cellulose, lipids, pigments and a } \\
\text { liquid rich in minerals of agricultural } \\
\text { importance. }\end{array}$ & $\begin{array}{l}\text { Council of Scientific \& } \\
\text { Industrial Research }\end{array}$ & India \\
\hline CN101024847 & $\begin{array}{l}\text { Method for producing } \\
\text { alcohol and feed by } \\
\text { utilising seaweed } \\
\text { chemical waste material }\end{array}$ & 2007 & Granted in China. & $\begin{array}{l}\text { A method for producing bioethanol } \\
\text { and feed from seaweed chemical waste } \\
\text { (kelp, Sargassum, macroalgae, } \\
\text { Ascophyllum nodosum, wakame, Hiijiki } \\
\text { and ropeweed). }\end{array}$ & Shandong University & China \\
\hline $\begin{array}{l}\text { US201 } \\
\text { 3005009A1 }\end{array}$ & $\begin{array}{l}\text { Process for integrated } \\
\text { production of ethanol and } \\
\text { seaweed sap from } \\
\text { Kappaphycus alverezii }\end{array}$ & 2009 & $\begin{array}{l}\text { Granted in China, } \\
\text { Europe, Japan and } \\
\text { the US. }\end{array}$ & $\begin{array}{l}\text { A process for production of bioethanol } \\
\text { and seaweed biofertilizer from fresh } \\
\text { seaweed Kappaphycus alverezii. }\end{array}$ & $\begin{array}{l}\text { Brahmbhatt Harshad } \\
\text { Ramanbhai, Council of } \\
\text { Scientific \& Industrial Research, } \\
\text { Eswaran K, Ghosh Pushpito, } \\
\text { Kumar, Gnanasekaran G, Jha } \\
\text { Bhavanath, Mody Kalpana } \\
\text { Haresh, Sana Barindra, Shah } \\
\text { Bharatiben Gunavantray, } \\
\text { Shukla Atindra Dinkerray, } \\
\text { Thampy Sreekumaran }\end{array}$ & India \\
\hline
\end{tabular}

\footnotetext{
${ }^{\text {a }}$ Patent number presented may be just one document or multiple documents that are filed in various countries covering similar or the same technical content.

b Status as of July 2021.
}

understanding that needs addressing to enable the successful commercialisation of their design and development. This section identifies and discusses what the authors believe to be key issues and challenges associated with macroalgal biorefineries (summarised in Table 5) that ought to be addressed, and the future directions required to fully exploit the potential of macroalgal biorefineries.

Macroalgae cultivation and supply. Problems related to macroalgal cultivation and harvesting, the availability of an annual feedstock supply chain, species selectivity and suitability, and the effective hydrolysis and conversion/utilisation of the unique polysaccharides inherent to macroalgae by conventional microorganisms [19,32] are hindrances which have been recognised by researchers and have previously been reported as factors restricting the commercialisation of macroalgal bio-refineries. Nonetheless, there is continued research to address these challenges.

Bioprocess scalability and integration. One major obstacle that could impede the development of macroalgal biorefineries, and requires further research, is the scalability of the biotechnologies that have been employed. At present, the vast majority of research has been conducted on laboratory-scale equipment and it is not clear how scalable some of these technologies will be. Furthermore, biorefineries that aim to generate more than two bioproducts will require the full integration of each particular unit operation [206] on a significantly larger scale, which to date, has not been trialled. Bioprocess efficiencies and bioproduct yields will also need to be re-evaluated to monitor losses which may arise due to the increase in scale.

Water utilisation and energy demand. Another significant issue that may prohibit the advancement of macroalgal biorefineries, are the necessary but extremely costly removal of water; washing; and drying steps that take place post-harvesting. A significant amount of research has been conducted on thoroughly washed biomass, typically using fresh or deionized water to remove salts, epiphytes and sand [207]. The removal of salt from the feedstock is also a vital requirement to prevent any corrosive damage inside bioreactors and the bioprocess 
Table 5

Challenges and issues associated with future macroalgal biorefineries.

Stage in biorefinery Potential challenges, issues and solutions
process

Upstream process Cultivation

Harvesting

Post-harvesting processing

Biotechnology conversion process

Downstream process
- Regulations and licensing of aquaculture are still relatively complex and vary according to country and international waters.

- Seasonality issues may affect biochemical composition and thus bioproduct potential.

- Biomass quantities could be variable per season, which would therefore affect TEA of the overall process.

- Scalability of cultivation and mass macroalgal farming requires further $R \& D$ and ought to be embedded within an IMTA approach.

- Public engagement/acceptance of seaweed farms (and biorefineries) in local coastal communities are needed to avoid public opposition. Early communication and transparency on responsible innovation aspects are essential to increase public acceptance.

- Shortage of skilled individuals with knowledge and practical experience may slow cultivation development. Further collaborations between research organisations (who have predominant knowledge of cultivation technologies) and commercial or governmental research entities needed, and the establishment of training programs would strengthen macroalgal cultivation techniques to drive the industry.

- Manual labour costs for harvesting of macroalgae vary according to country and could be relatively costly. Novel approaches to automated harvesting may alleviate manual labour and overheads.

- Storage of harvested macroalgae associated difficulties and transportation issues/costs exist at present. Location of future biorefinery plants may have to be within close proximity to cultivation and harvesting/ farming site.

- Dewatering of macroalgal biomass and the removal of salt are necessary pre-processing steps to aid subsequent bioprocessing, transportation and for massbalance calculation purposes but are energy-intensive and costly. Macroalgal processing may have to be performed on wet biomass, or biorefinery plant may have to be on on-site or close to macroalgal farm. - Estimation of individual product value difficult and hence choice of product mix within integrated whole biorefinery subject to uncertainty and risk. - Biocompatibility of bioprocesses and technologies need to be understood and tailored towards each species of macroalgae, and ensure utilisation of all biochemical fractions. Insights into how variable processing parameters influence the overall bioprocess and bioproduct formation are also required.

- Bioprocessing technologies currently function as unit operations. Further research is required to fully integrate each unit of operation for multiple applications within a biorefinery such as biofuels and bioproducts.

- Several successful biotechnology processes developed for macroalgae have been demonstrated at laboratory scale, yet their potential for scalability is often overlooked. The reliability and efficiency of the processes for commercialisation need investigating.

- Sustainability features of macroalgal biorefineries need further investigation with multiple and advanced environmental assessment tools such as emergy/LCA/ and exergy-based methods.

- Separation technologies suitable for each bio-product require development, selectivity, and efficiency.

- Product purity and impurity profiles need to consistently meet regulatory requirements of end use applications.

- Bio-product types and yields may vary according to macroalgal species initially used as feedstock and biochemical composition. The seasonal growth and availability of different macroalgae species ought to be
Table 5 (continued)

\begin{tabular}{ll}
$\begin{array}{l}\text { Stage in biorefinery } \\
\text { process }\end{array}$ & Potential challenges, issues and solutions \\
\hline & $\begin{array}{l}\text { considered for biorefinery processes, and the range of } \\
\text { bio-products and biofuels that can be obtained per } \\
\text { annum. }\end{array}$ \\
\hline
\end{tabular}

infrastructure itself, as well as potential effects on downstream chemical and biological processes such as pretreatments and microbial fermentations [137]. Furthermore, subsequent stages within a bioprocess all require fresh water thus ultimately increasing the water footprint of any given biorefinery, which is particularly concerning since global freshwater sources are limited [208]. For example, in the specific case of bioethanol production alone, the water footprint ranges from around 1.5 to $10 \mathrm{~L}$ of water for each litre of bioethanol produced [209]. In light of this, researchers have started to investigate ways of incorporating seawater, or salt water, into bioprocesses, and have shown the feasibility of utilising seawater in both the hydrolysis and fractionation of macroalgae [210,211], and fermentation into bioethanol [210,212,213]. It should be noted, however, that although these studies have highlighted the technical ability of employing seawater in a specifically distinct process, the application of the sole use of seawater within an entire macroalgal biorefinery process, which consists of combined unit operations, is still yet to be achieved. Further research is required to evaluate whether each unit operation in a biorefinery can be interlinked with seawater, and what impacts this may have on the overall bioprocess, range of bioproducts, bioproduct yield and purity, and their applications. Nonetheless, the potential for an entirely salt-based macroalgal biorefinery is starting to become promising.

Overall biorefinery process design and environmental sustainability. An understanding of the optimal, holistic and integrated bioprocessing pathways for each species of macroalgae, that can be cultivated sustainably at scale off-shore, is required along with the range of potential bioproducts and biofuels that can be generated. Such information will be vital for the future of the bioeconomy in terms of sustainability and economic benefit. Each bioprocessing pathway ought to be logged in a central database that is available globally along with the plethora of potential bioproducts, as this will enable the macroalgal industry to continue to prosper. Although this may appear to be overly optimistic, it is entirely feasible with strong collaborative links between academia and industries, and multidisciplinary groups consisting of bioscientists, marine biologists, cultivation specialists, engineers and social scientists. Such collaborations are key to the pursuit of this field. With optimal bioprocessing routes identified and logged, it is additionally important that the sustainability features of each seaweed specific bioprocess are accurately assessed using different advanced environmental assessment tools. These include LCA, exergy and emergy-based models that will help to advance the seaweed industry, and recommend the excellent article published by Rosen [214] where these assessment tools are explained in greater detail for the reader.

Adaptability to specific geographic and regulatory constraints. Challenges will include, for example, the need to overcome significant differences in each countries' regulations and licensing of macroalgal farms for species that have potential for off-shore cultivation, the temperament of native species of macroalgae belonging to the waters of each country, and the differences and affordability of bioprocessing technologies tailored for each species. Additionally, it is recognised that the range of bioproducts may differ according to country, as biorefineries will utilise species that are native to each country's coastal waters. This could potentially have an impact on the bioeconomy of each country, or coastal region, as the biochemical constituents of macroalgae, which essentially dictate the range of potential bioproducts that can be produced, differ according to taxonomical group. Furthermore, there may also be the challenge of obtaining planning permission to build a biorefinery at a coastal area, with laws differing between 
countries.

Resilience to environmental change. There is a possibility that the bioeconomy infrastructure of an individual country may also dramatically change in future decades, due to the influences of global warming. Studies have demonstrated potential changes in the geographical distribution and abundance of macroalgae in different coastal environments as a result of rising temperatures due to climate change [215-219]. Macroalgal distribution shifts will inevitably affect established macroalgal biorefineries, their sites, jobs, and the overall prosperity of the bioeconomy. It is vital, therefore, that species distribution studies continue to model and project how macroalgal species of commercial interest continue to change in response to climate change. Sustained research and development of novel macroalgal biorefineries will be a necessary requirement in the decades to come, as farming sites may eventually face depleted feedstock sources, or new species invasions due to distribution shifts.

Public/local community acceptance and economic impact. Although the development of large-scale biorefineries at coastal sites (and off-shore macroalgae cultivation systems which ideally ought to be in close geographical proximity), will undoubtedly provide societal benefits, including job creation, energy security and economic development through employment [220], there may be opposition from the public and local community. To ensure the social acceptance of biorefineries, responsible innovation approaches need to be considered and implemented in order to gain public acceptance. This could be achieved by educating coastal communities of the biotechnologies and benefits before the biorefinery is introduced. Delivery through open and inclusive focus group meetings and/or workshops could serve as a platform to engage academics, funders, stakeholders and the public.

\section{Conclusions}

Macroalgae have shown, and will continue to display, a remarkable potential for their incorporation within the landscape of future biorefineries. Research studies have highlighted promising biochemical processing routes, utilising a range of different species of macroalgae belonging to the three taxonomical groups, for the generation of biofuels, bioproducts and high value biochemicals. The increasing interest and applications of macroalgal intellectual property, along with the number of funded research projects across the entire macroalgal biorefinery pathway, underpins global awareness of their exciting prospective to contribute towards the bioeconomy and serve as a sustainable renewable feedstock. However, it is clear that macroalgal biorefineries are still in their infancy and the associated biotechnologies, which show promise, are yet to proceed beyond the laboratory to industrial scale. Nevertheless, macroalgal bioproducts and biofuels have the aptitude to influence the progression of government policy and regulations development, which would enable countries to continue to establish bioeconomic strategies and drive the urgent necessity of avoiding the use of finite non-renewable sources. This would ultimately require successful scale up of efficient macroalgal biorefinery processes, yet with effective transfer of knowledge and transparency between academia, industry, stakeholders, government and the public, the commercialisation of such biorefineries will eventually become a reality.

\section{Declaration of competing interest}

The authors declare that they have no known competing financial interests or personal relationships that could have appeared to influence the work reported in this paper.

\section{Acknowledgements}

ETK acknowledges support in the form of a Discovery Fellowship from the UK Biotechnology and Biological Sciences Research Council,
BBSRC (BB/S010610/1). Support for GJL from the Future Biomanufacturing Research Hub (EP/S01778X/1), funded by the Engineering and Physical Sciences Research Council (EPSRC) and BBSRC as part of UK Research and Innovation is also acknowledged.

\section{References}

[1] UN. World population prospects 2019: highlights (st/esa/ser. A/423). In: UN, editor. New York, NY2019.

[2] Mohan SV, Nikhil G, Chiranjeevi P, Reddy CN, Rohit M, Kumar AN, et al. Waste biorefinery models towards sustainable circular bioeconomy: critical review and future perspectives. Bioresour Technol 2016;215:2-12.

[3] Sanz-Hernández A, Esteban E, Garrido P. Transition to a bioeconomy: perspectives from social sciences. J Clean Prod 2019.

[4] Transforming UN. Our world: the 2030 agenda for sustainable development. New York: United Nations; 2016.

[5] Heimann T. Bioeconomy and SDGs: does the bioeconomy support the achievement of the SDGs? Earth's Future. 2019;7:43-57.

[6] Strategy Bioeconomy. A sustainable bioeconomy for Europe: strengthening the connection between economy, society and the environment. In: European commission; 2018. Brussels, Belgium.

[7] Ronzon T, Sanjuán AI. Friends or foes? A compatibility assessment of bioeconomy-related Sustainable Development Goals for European policy coherence. J Clean Prod 2020;254:119832.

[8] Government of United Kingdom. Growing the bioeconomy: a national bioeconomy strategy to 2030. 2018.

[9] Tursi A. A review on biomass: importance, chemistry, classification, and conversion. Biofuel Research Journal 2019;6:962-79.

[10] Barbier M, Araújo R, Rebours C, Jacquemin B, Holdt SL, Charrier B. Development and objectives of the PHYCOMORPH European guidelines for the sustainable aquaculture of seaweeds (PEGASUS). Bot Mar 2020.

[11] Hassan SS, Williams GA, Jaiswal AK. Moving towards the second generation of lignocellulosic biorefineries in the EU: drivers, challenges, and opportunities. Renew Sustain Energy Rev 2019;101:590-9.

[12] Adams J, Toop T, Donnison IS, Gallagher JA. Seasonal variation in Laminaria digitata and its impact on biochemical conversion routes to biofuels. Bioresour Technol 2011;102:9976-84.

[13] Ge L, Wang P, Mou H. Study on saccharification techniques of seaweed wastes for the transformation of ethanol. Renew Energy Focus 2011;36:84-9.

[14] Alalwan HA, Alminshid AH, Aljaafari HA. Promising evolution of biofuel generations. Subject review. Renew Energy Focus 2019;28:127-39.

[15] Gaurav N, Sivasankari S, Kiran G, Ninawe A, Selvin J. Utilization of bioresources for sustainable biofuels: a review. Renew Sustain Energy Rev 2017;73:205-14.

[16] Li Y, Cui J, Zhang G, Liu Z, Guan H, Hwang H, et al. Optimization study on the hydrogen peroxide pretreatment and production of bioethanol from seaweed Ulva prolifera biomass. Bioresour Technol 2016;214:144-9.

[17] Fao. The state of world fisheries and aquaculture 2016. Contributing to food security and nutrition for all. Rome: Food \& Agriculture Org; vol. 2016.

[18] Araújo R, Calderón FV, López JS, Azevedo IC, Bruhn A, Fluch S, et al. Current status of the algae production industry in Europe: an emerging sector of the Blue Bioeconomy. Front Mar Sci 2021;7.

[19] Rajak RC, Jacob S, Kim BS. A holistic zero waste biorefinery approach for macroalgal biomass utilization: a review. Sci Total Environ 2020;716:137067.

[20] Torres M, Kraan S, Domínguez H. Seaweed biorefinery. Rev Environ Sci Biotechnol 2019;18:335-88.

[21] Filote C, Santos SC, Popa VI, Botelho CM, Volf I. Biorefinery of marine macroalgae into high-tech bioproducts: a review. Environ Chem Lett 2020:1-32.

[22] Jung KA, Lim S-R, Kim Y, Park JM. Potentials of macroalgae as feedstocks for biorefinery. Bioresour Technol 2013;135:182-90.

[23] Zollmann M, Robin A, Prabhu M, Polikovsky M, Gillis A, Greiserman S, et al. Green technology in green macroalgal biorefineries. Phycologia 2019;58:516-34.

[24] Álvarez-Viñas M, Flórez-Fernández N, Torres MD, Domínguez H. Successful approaches for a red seaweed biorefinery. Mar Drugs 2019;17:620.

[25] Intellectual Property Office. Patent grant timeline. 2019.

[26] Lordan S, Ross RP, Stanton C. Marine bioactives as functional food ingredients: potential to reduce the incidence of chronic diseases. Mar Drugs 2011;9: 1056-100.

[27] Bocanegra A, Bastida S, Benedi J, Rodenas S, Sanchez-Muniz FJ. Characteristics and nutritional and cardiovascular-health properties of seaweeds. J Med Food 2009;12:236-58.

[28] Ramos MV, Monteiro ACO, Moreira RA, Carvalho ADF. Amino acid composition of some Brazilian seaweed species. J Food Biochem 2000;24:33-9. aFU.

[29] Morais T, Inácio A, Coutinho T, Ministro M, Cotas J, Pereira L, et al. Seaweed potential in the animal feed: a review. J Mar Sci Eng 2020;8:559.

[30] Fleurence J. Seaweed proteins: biochemical, nutritional aspects and potential uses. Trends Food Sci Technol 1999;10:25-8.

[31] Yanik J, Stahl R, Troeger N, Sinag A. Pyrolysis of algal biomass. J Anal Appl Pyrolysis 2013;103:134-41.

[32] Kostas ET, White DA, Du C, Cook DJ. Selection of yeast strains for bioethanol production from UK seaweeds. J Appl Phycol 2016;28:1427-41.

[33] Schiener P, Black KD, Stanley MS, Green DH. The seasonal variation in the chemical composition of the kelp species Laminaria digitata, Laminaria hyperborea, Saccharina latissima and Alaria esculenta. J Appl Phycol 2015;27:363-73. 
[34] McDermid KJ, Stuercke B. Nutritional composition of edible Hawaiian seaweeds. J Appl Phycol 2003;15:513-24.

[35] Kumari P, Kumar M, Gupta V, Reddy C, Jha B. Tropical marine macroalgae as potential sources of nutritionally important PUFAs. Food Chem 2010;120: 749-57.

[36] Yuan YV, Bone DE, Carrington MF. Antioxidant activity of dulse (Palmaria palmata) extract evaluated in vitro. Food Chem 2005;91:485-94.

[37] Al-Azzawie HF, Alhamdani M-SS. Hypoglycemic and antioxidant effect of oleuropein in alloxan-diabetic rabbits. Life Sci 2006;78:1371-7.

[38] Urquiaga I, Leighton F. Plant polyphenol antioxidants and oxidative stress. Biol Res 2000;33:55-64.

[39] Lopes G, Sousa C, Silva LR, Pinto E, Andrade PB, Bernardo J, et al. Can phlorotannins purified extracts constitute a novel pharmacological alternative for microbial infections with associated inflammatory conditions? PloS One 2012;7: e31145.

[40] Kajiwara T, Matsui K, Akakabe Y, Murakawa T, Arai C. Antimicrobial browninginhibitory effect of flavor compounds in seaweeds. J Appl Phycol 2006;18: 413-22.

[41] Morán-Santibañez K, Peña-Hernández MA, Cruz-Suárez LE, Ricque-Marie D, Skouta R, Vasquez AH, et al. Virucidal and synergistic activity of polyphenol-rich extracts of seaweeds against measles virus. Viruses 2018;10:465.

[42] Iwai K. Antidiabetic and antioxidant effects of polyphenols in brown alga Ecklonic stolonifera in genetically diabetic KK-A y mice. Plant Foods Hum Nutr 2008;63: 163.

[43] Zenthoefer M, Geisen U, Hofmann-Peiker K, Fuhrmann M, Kerber J, Kirchhöfer R, et al. Isolation of polyphenols with anticancer activity from the Baltic Sea brown seaweed Fucus vesiculosus using bioassay-guided fractionation. J Appl Phycol 2017;29:2021-37.

[44] Murugan AC, Vallal D, Karim MR, Govindan N, Yusoff M, Rahman MM. In vitro antiradical and neuroprotective activity of polyphenolic extract from marine algae Padina australis H. J Chem Pharmaceut Res 2015;7:355-62.

[45] Kang M-C, Ahn G, Yang X, Kim K-N, Kang S-M, Lee S-H, et al. Hepatoprotective effects of dieckol-rich phlorotannins from Ecklonia cava, a brown seaweed, against ethanol induced liver damage in BALB/c mice. Food Chem Toxicol 2012 50:1986-91.

[46] Gómez-Guzmán M, Rodríguez-Nogales A, Algieri F, Gálvez J. Potential role of seaweed polyphenols in cardiovascular-associated disorders. Mar Drugs 2018;16: 250.

[47] Marsham S, Scott GW, Tobin ML. Comparison of nutritive chemistry of a range of temperate seaweeds. Food Chem 2007;100:1331-6.

[48] Dethier MN, Williams SL. Seasonal stresses shift optimal intertidal algal habitats. Mar Biol 2009;156:555-67.

[49] Pablo G, Gomes-Dias JS, Rocha CM, Romaní A, Garrote G, Domingues L. Recent trends on seaweed fractionation for liquid biofuels production. Bioresour Technol 2020;299:122613.

[50] Offei F, Mensah M, Thygesen A, Kemausuor F. Seaweed bioethanol production: a process selection review on hydrolysis and fermentation. Fermentatio 2018;4:99.

[51] Campo VL, Kawano DF, da Silva Jr DB, Carvalho I. Carrageenans: biological properties, chemical modifications and structural analysis-A review. Carbohydr Polym 2009;77:167-80.

[52] Stanley N. Production, properties and uses of carrageenan. Production and utilization of products from commercial seaweeds FAO Fisheries Technical Paper 1987;288:116-46.

[53] Préchoux A, Genicot S, Rogniaux H, Helbert W. Controlling carrageenan structure using a novel formylglycine-dependent sulfatase, an endo-4S-iota-carrageenan sulfatase. Mar Biotechnol 2013;15:265-74.

[54] Cregut M, Rondags E. New insights in agar biorefinery with arylsulphatase activities. Process Biochem 2013;48:1861-71.

[55] Schafer SE, Stevens ES. A reexamination of the double-helix model for agarose gels using optical rotation. Biopolymers 1995;36:103-8.

[56] Sudhakar K, Mamat R, Samykano M, Azmi W, Ishak W, Yusaf T. An overview of marine macroalgae as bioresource. Renew Sustain Energy Rev 2018;91:165-79.

[57] O'Sullivan L, Murphy B, McLoughlin P, Duggan P, Lawlor PG, Hughes H, et al. Prebiotics from marine macroalgae for human and animal health applications. Mar Drugs 2010;8:2038-64.

[58] Percival E, McDowell RH. Chemistry and enzymology of marine algal polysaccharides. London: Academic Press; 1967.

[59] Chiellini F, Morelli A. Ulvan: a versatile platform of biomaterials from renewable resources. Biomaterials_-Physics and Chemistry 2011:75-98.

[60] Cunha L, Grenha A. Sulfated seaweed polysaccharides as multifunctional materials in drug delivery applications. Mar Drugs 2016;14:42.

[61] Stadnik MJ, Freitas MBd. Algal polysaccharides as source of plant resistance inducers. Trop Plant Pathol 2014;39:111-8.

[62] Tziveleka L-A, Ioannou E, Roussis V. Ulvan, a bioactive marine sulphated polysaccharide as a key constituent of hybrid biomaterials: a review. Carbohydr Polym 2019;218:355-70.

[63] Manns D, Deutschle AL, Saake B, Meyer AS. Methodology for quantitative determination of the carbohydrate composition of brown seaweeds (Laminariaceae). RSC Adv 2014;4:25736-46.

[64] Davis TA, Llanes F, Volesky B, Diaz-Pulido G, McCook L, Mucci A. 1 H-NMR study of Na alginates extracted from Sargassum spp. in relation to metal biosorption. Appl Biochem Biotechnol 2003;110:75-90.

[65] Draget KI, Smidsrød O, Skjåk-Bræk G. Alginates from algae. Biopolymers 2005;6.

[66] Cardoso S, Carvalho G, J Silva P, Rodrigues S, R Pereira O, Pereira L. Bioproducts from seaweeds: a review with special focus on the Iberian Peninsula. Curr Org Chem 2014;18:896-917.
[67] Morya V, Kim J, Kim E-K. Algal fucoidan: structural and size-dependent bioactivities and their perspectives. Appl Microbiol Biotechnol 2012;93:71-82.

[68] Venugopal V. Seaweed: nutritional value, bioactive properties, and uses. Boca Raton: CRC Press; 2009.

[69] Yuan Y, Macquarrie D. Microwave assisted extraction of sulfated polysaccharides (fucoidan) from Ascophyllum nodosum and its antioxidant activity. Carbohydr Polym 2015;129:101-7.

[70] Ponce NM, Pujol CA, Damonte EB, Flores MaL, Stortz CA. Fucoidans from the brown seaweed Adenocystis utricularis: extraction methods, antiviral activity and structural studies. Carbohydr Res 2003;338:153-65.

[71] Park HY, Han MH, Park C, Jin C-Y, Kim G-Y, Choi I-W, et al. Anti-inflammatory effects of fucoidan through inhibition of NF-kB, MAPK and Akt activation in lipopolysaccharide-induced BV2 microglia cells. Food Chem Toxicol 2011;49: 1745-52.

[72] Shen HY, Li LZ, Xue KC, Hu DD, Gao YJ. Antitumor activity of fucoidan in anaplastic thyroid cancer via apoptosis and anti-angiogenesis. Mol Med Rep 2017;15:2620-4.

[73] Ale MT, Meyer AS. Fucoidans from brown seaweeds: an update on structures, extraction techniques and use of enzymes as tools for structural elucidation. RSC Adv 2013;3:8131-41.

[74] Horn S, Aasen I, Østgaard K. Ethanol production from seaweed extract. J Ind Microbiol 2000;25:249-54.

[75] Rioux L-E, Beaulieu L, Turgeon SL. Seaweeds: a traditional ingredients for new gastronomic sensation. Food Hydrocolloids 2017;68:255-65.

[76] Lee JY, Kim Y-J, Kim HJ, Kim Y-S, Park W. Immunostimulatory effect of laminarin on RAW 264.7 mouse macrophages. Molecules 2012;17:5404-11.

[77] Muraille L, Aguié-Beghin V, Chabbert B, Molinari M. Bioinspired lignocellulosic films to understand the mechanical properties of lignified plant cell walls at nanoscale. Sci Rep 2017;7:1-11.

[78] Suganya T, Varman M, Masjuki H, Renganathan S. Macroalgae and microalgae as a potential source for commercial applications along with biofuels production: a biorefinery approach. Renew Sustain Energy Rev 2016;55:909-41.

[79] Deniaud-Bouët E, Hardouin K, Potin P, Kloareg B, Hervé C. A review about brown algal cell walls and fucose-containing sulfated polysaccharides: cell wall context, biomedical properties and key research challenges. Carbohydr Polym 2017;175: 395-408.

[80] Stiger-Pouvreau V, Bourgougnon N, Deslandes E. Carbohydrates from seaweeds. In: Fleurence J, Levine I, editors. Seaweed in health and disease prevention. Elsevier; 2016. p. 223-74.

[81] Rees DA. Polysaccharide shapes and their interactions-some recent advances. Pure Appl Chem 1981;53:1-14.

[82] Youssef NH, Farag IF, Rinke C, Hallam SJ, Woyke T, Elshahed MS. In Silico analysis of the metabolic potential and niche specialization of candidate phylum" Latescibacteria"(WS3). PloS One 2015;10:e0127499.

[83] Lahaye M, Robic A. Structure and functional properties of ulvan, a polysaccharide from green seaweeds. Biomacromolecules 2007;8:1765-74.

[84] Deniaud-Bouët E, Kervarec N, Michel G, Tonon T, Kloareg B, Hervé C. Chemical and enzymatic fractionation of cell walls from Fucales: insights into the structure of the extracellular matrix of brown algae. Ann Bot 2014;114:1203-16.

[85] Postma P, Cerezo-Chinarro O, Akkerman R, Olivieri G, Wijffels RH, Brandenburg W, et al. Biorefinery of the macroalgae Ulva lactuca: extraction of proteins and carbohydrates by mild disintegration. J Appl Phycol 2018;30: 1281-93.

[86] Ferdouse F, Holdt SL, Smith R, Murua P, Yang Z. The global status of seaweed production, trade and utilization. Food and Agriculture Organization of the United Nations; 2018.

[87] van den Burg S, Dagevos H, Helmes R. Towards sustainable European seaweed value chains: a triple P perspective. ICES J Mar Sci 2019.

[88] Buschmann AH, Camus C, Infante J, Neori A, Israel Á, Hernández-González MC, et al. Seaweed production: overview of the global state of exploitation, farming and emerging research activity. Eur J Phycol 2017;52:391-406.

[89] Alemañ AE, Robledo D, Hayashi L. Development of seaweed cultivation in Latin America: current trends and future prospects. Phycologia 2019;58:462-71.

[90] Jansen HM, Van Den Burg S, Bolman B, Jak RG, Kamermans P, Poelman M, et al. The feasibility of offshore aquaculture and its potential for multi-use in the North Sea. Aquacult Int 2016;24:735-56.

[91] Troell M, Joyce A, Chopin T, Neori A, Buschmann AH, Fang J-G. Ecological engineering in aquaculture - potential for integrated multi-trophic aquaculture (IMTA) in marine offshore systems. Aquaculture 2009;297:1-9.

[92] Aitken D, Bulboa C, Godoy-Faundez A, Turrion-Gomez JL, Antizar-Ladislao B. Life cycle assessment of macroalgae cultivation and processing for biofuel production. J Clean Prod 2014:75:45-56.

[93] Buck BH, Krause G, Michler-Cieluch T, Brenner M, Buchholz C, Busch J, et al. Meeting the quest for spatial efficiency: progress and prospects of extensive aquaculture within offshore wind farms. Helgol Mar Res 2008;62:269-81.

[94] Campbell I, Macleod A, Sahlmann C, Neves L, Funderud J, Øverland M, et al. The environmental risks associated with the development of seaweed farming in Europe-prioritizing key knowledge gaps. Front Mar Sci 2019.

[95] Fernand F, Israel A, Skjermo J, Wichard T, Timmermans KR, Golberg A. Offshore macroalgae biomass for bioenergy production: environmental aspects, technological achievements and challenges. Renew Sustain Energy Rev 2017;75: 35-45.

[96] Kerrison PD, Stanley MS, Edwards MD, Black KD, Hughes AD. The cultivation of European kelp for bioenergy: site and species selection. Biomass Bioenergy 2015; 80:229-42. 
[97] Stévant P, Rebours C, Chapman A. Seaweed aquaculture in Norway: recent industrial developments and future perspectives. Aquacult Int 2017;25:1373-90.

[98] Kim JK, Yarish C, Hwang EK, Park M, Kim Y, Kim JK, et al. Seaweed aquaculture: cultivation technologies, challenges and its ecosystem services. ALGAE 2017;32 $1-13$.

[99] Brunori G. Sustainable agriculture, forestry and fisheries in the bioeconomy-A challenge for Europe. EU Commission; 2015.

[100] Cesário MT, da Fonseca MMR, Marques MM, de Almeida MCM. Marine algal carbohydrates as carbon sources for the production of biochemicals and biomaterials. Biotechnol Adv 2018;36:798-817.

[101] Prabhu MS, Israel A, Palatnik RR, Zilberman D, Golberg A. Integrated biorefinery process for sustainable fractionation of Ulva ohnoi (Chlorophyta): process optimization and revenue analysis. J Appl Phycol 2020:1-12.

[102] Khoo CG, Dasan YK, Lam MK, Lee KT. Algae biorefinery: review on a broad spectrum of downstream processes and products. Bioresour Technol 2019;292: 121964.

[103] Pablo G, Domínguez E, Domínguez VD, Romaní A, Domingues L, Garrote G. Third generation bioethanol from invasive macroalgae Sargassum muticum using autohydrolysis pretreatment as first step of a biorefinery. Renew Energy 2019; 141:728-35.

[104] Kostas ET, Beneroso D, Robinson JP. The application of microwave heating in bioenergy: a review on the microwave pre-treatment and upgrading technologies for biomass. Renew Sustain Energy Rev 2017;77:12-27.

[105] Ramachandra T, Hebbale D. Bioethanol from macroalgae: prospects and challenges. Renew Sustain Energy Rev 2020;117:109479.

[106] Cheah WY, Sankaran R, Show PL, Ibrahim TNBT, Chew KW, Culaba A, et al. Pretreatment methods for lignocellulosic biofuels production: current advances, challenges and future prospects. Biofuel Research Journal 2020;7:1115.

[107] Peñuela A, Robledo D, Bourgougnon N, Bedoux G, Hernández-Núñez E, FreilePelegrín Y. Environmentally friendly valorization of Solieria filiformis (Gigartinales, Rhodophyta) from IMTA using a biorefinery concept. Mar Drugs 2018; $16: 487$.

[108] Masarin F, Cedeno FRP, Chavez EGS, De Oliveira LE, Gelli VC, Monti R. Chemical analysis and biorefinery of red algae Kappaphycus alvarezii for efficient production of glucose from residue of carrageenan extraction process. Biotechnol Biofuels 2016;9:122.

[109] Kumar S, Gupta R, Kumar G, Sahoo D, Kuhad RC. Bioethanol production from Gracilaria verrucosa, a red alga, in a biorefinery approach. Bioresour Technol 2013;135:150-6.

[110] Kang S, Fu J, Zhang G. From lignocellulosic biomass to levulinic acid: a review on acid-catalyzed hydrolysis. Renew Sustain Energy Rev 2018;94:340-62.

[111] Cao L, Iris K, Cho D-W, Wang D, Tsang DC, Zhang S, et al. Microwave-assisted low-temperature hydrothermal treatment of red seaweed (Gracilaria lemaneiformis) for production of levulinic acid and algae hydrochar. Bioresour Technol 2019;273:251-8.

[112] Francavilla M, Manara P, Kamaterou P, Monteleone M, Zabaniotou A. Cascade approach of red macroalgae Gracilaria gracilis sustainable valorization by extraction of phycobiliproteins and pyrolysis of residue. Bioresour Technol 2015; 184:305-13.

[113] Adams JM, Turner LB, Toop TA, Kirby ME, Rolin C, Judd E, et al. Evaluation of pyrolysis chars derived from marine macroalgae silage as soil amendments. Glob Change Biol Bioenergy 2020;12:706-27.

[114] Baghel RS, Trivedi N, Gupta V, Neori A, Reddy C, Lali A, et al. Biorefining of marine macroalgal biomass for production of biofuel and commodity chemicals. Green Chem 2015;17:2436-43.

[115] Baghel RS, Trivedi N, Reddy C. A simple process for recovery of a stream of products from marine macroalgal biomass. Bioresour Technol 2016;203:160-5.

[116] Offei F, Mensah M, Kemausuor F, Thygesen A. A biorefinery approach to bioethanol and bioelectricity co-production from tropical seaweeds. J Appl Phycol 2019;31:3899-913.

[117] van der Wal H, Sperber BL, Houweling-Tan B, Bakker RR, Brandenburg W, LópezContreras AM. Production of acetone, butanol, and ethanol from biomass of the green seaweed Ulva lactuca. Bioresour Technol 2013;128:431-7.

[118] Mata L, Magnusson M, Paul NA, de Nys R. The intensive land-based production of the green seaweeds Derbesia tenuissima and Ulva ohnoi: biomass and bioproducts J Appl Phycol 2016;28:365-75.

[119] Carl C, Magnusson M, Paul NA, de Nys R. The yield and quality of multiple harvests of filamentous Ulva tepida. J Appl Phycol 2016;28:2865-73.

[120] Paul NA, Neveux N, Magnusson M, De Nys R. Comparative production and nutritional value of "sea grapes"- the tropical green seaweeds Caulerpa lentillifera and C. racemosa. J Appl Phycol 2014;26:1833-44.

[121] Magnusson M, Carl C, Mata L, de Nys R, Paul NA. Seaweed salt from Ulva: a novel first step in a cascading biorefinery model. Algal Res 2016;16:308-16.

[122] Glasson CR, Sims IM, Carnachan SM, de Nys R, Magnusson M. A cascading biorefinery process targeting sulfated polysaccharides (ulvan) from Ulva ohnoi. Algal Res 2017;27:383-91.

[123] Magnusson M, Glasson CR, Vucko MJ, Angell A, Neoh TL, de Nys R. Enrichmen processes for the production of high-protein feed from the green seaweed Ulva ohnoi. Algal Res 2019;41:101555.

[124] Esquivel-Hernández DA, Ibarra-Garza IP, Rodríguez-Rodríguez J, CuéllarBermúdez SP, Rostro-Alanis MdJ, Alemán-Nava GS, et al. Green extraction technologies for high-value metabolites from algae: a review. Biofuel Bioprod Biorefin 2017;11:215-31.

[125] Polikovsky M, Gillis A, Steinbruch E, Robin A, Epstein M, Kribus A, et al. Biorefinery for the co-production of protein, hydrochar and additional co- products from a green seaweed Ulva sp. with subcritical water hydrolysis. Energy Convers Manag 2020;225:113380.

[126] Trivedi N, Baghel RS, Bothwell J, Gupta V, Reddy C, Lali AM, et al. An integrated process for the extraction of fuel and chemicals from marine macroalgal biomass. Sci Rep 2016;6:30728.

[127] Mhatre A, Gore S, Mhatre A, Trivedi N, Sharma M, Pandit R, et al. Effect of multiple product extractions on bio-methane potential of marine macrophytic green alga Ulva lactuca. Renew Energy 2019;132:742-51.

[128] Yahmed NB, Jmel MA, Alaya MB, Bouallagui H, Marzouki MN, Smaali I. A biorefinery concept using the green macroalgae Chaetomorpha linum for the coproduction of bioethanol and biogas. Energy Convers Manag 2016;119:257-65.

[129] González-López N, Moure A, Domínguez H. Hydrothermal fractionation of Sargassum muticum biomass. J Appl Phycol 2012;24:1569-78.

[130] Balboa EM, Moure A, Domínguez H. Valorization of Sargassum muticum biomass according to the biorefinery concept. Mar Drugs 2015;13:3745-60.

[131] Ibañez E, Cifuentes A. Benefits of using algae as natural sources of functional ingredients. J Sci Food Agric 2013;93:703-9.

[132] Pérez L, Conde E, Domínguez H. Microwave hydrodiffusion and gravity processing of Sargassum muticum. Process Biochem 2014;49:981-8.

[133] Abraham RE, Su P, Puri M, Raston CL, Zhang W. Optimisation of biorefinery production of alginate, fucoidan and laminarin from brown seaweed Durvillaea potatorum. Algal Res 2019;38:101389.

[134] Kostas ET, White DA, Cook DJ. Development of a bio-refinery process for the production of speciality chemical, biofuel and bioactive compounds from Laminaria digitata. Algal Res 2017;28:211-9.

[135] Kostas ET, Williams OS, Duran-Jimenez G, Tapper AJ, Cooper M, Meehan R, et al. Microwave pyrolysis of Laminaria digitata to produce unique seaweed-derived biooils. Biomass Bioenergy 2019;125:41-9.

[136] Barreiro DL, Prins W, Ronsse F, Brilman W. Hydrothermal liquefaction (HTL) of microalgae for biofuel production: state of the art review and future prospects. Biomass Bioenergy 2013;53:113-27.

[137] Raikova S, Le C, Beacham TA, Jenkins R, Allen M, Chuck C. Towards a marine biorefinery through the hydrothermal liquefaction of macroalgae native to the United Kingdom. Biomass Bioenergy 2017;107:244-53.

[138] Knauer J, Southgate PC. A review of the nutritional requirements of bivalves and the development of alternative and artificial diets for bivalve aquaculture. Rev Fish Sci 1999;7:241-80.

[139] Schiener P, Atack T, Wareing R, Kelly MS, Hughes AD. The by-products from marine biofuels as a feed source for the aquaculture industry: a novel example of the biorefinery approach. Biomass Convers Biorefin 2016;6:281-7.

[140] Filote C, Volf I, Santos SC, Botelho CM. Bioadsorptive removal of Pb (II) from aqueous solution by the biorefinery waste of Fucus spiralis. Sci Total Environ 2019;648:1201-9.

[141] Jeffery S, Verheijen FG, van der Velde M, Bastos AC. A quantitative review of the effects of biochar application to soils on crop productivity using meta-analysis. Agric Ecosyst Environ 2011;144:175-87.

[142] McHugh DJ. A guide to the seaweed industry. Rome: FAO Fisheries Technical Paper 441 Food and Agriculture Organisation of the United Nations; 2003.

[143] Cardoso M, Carvalho G, J Silva P, Rodrigues S, R Pereira O, Pereira L. Bioproducts from seaweeds: a review with special focus on the Iberian Peninsula. Curr Org Chem 2014;18:896-917.

[144] Higashimura Y, Naito Y, Takagi T, Mizushima K, Hirai Y, Harusato A, et al. Oligosaccharides from agar inhibit murine intestinal inflammation through the induction of heme oxygenase-1 expression. J Gastroenterol 2013;48:897-909.

[145] Khan BM, Qiu H-M, Wang X-F, Liu Z-Y, Zhang J-Y, Guo Y-J, et al. Physicochemical characterization of Gracilaria chouae sulfated polysaccharides and their antioxidant potential. Int J Biol Macromol 2019;134:255-61.

[146] Cui M, Wu J, Wang S, Shu H, Zhang M, Liu K, et al. Characterization and antiinflammatory effects of sulfated polysaccharide from the red seaweed Gelidium pacificum Okamura. Int J Biol Macromol 2019;129:377-85.

[147] Adrien A, Bonnet A, Dufour D, Baudouin S, Maugard T, Bridiau N. Anticoagulant activity of sulfated ulvan isolated from the green macroalga Ulva rigida. Mar Drugs 2019;17:291.

[148] do-Amaral C, Pacheco B, Seixas F, Pereira C, Collares T. Antitumoral effects of fucoidan on bladder cancer. Algal Res 2020;47:101884.

[149] Patel S. Therapeutic importance of sulfated polysaccharides from seaweeds: updating the recent findings. 3 Biotech 2012;2:171-85.

[150] Li Z, Ramay HR, Hauch KD, Xiao D, Zhang M. Chitosan-alginate hybrid scaffolds for bone tissue engineering. Biomaterials 2005;26:3919-28.

[151] Kuo CK, Ma PX. Ionically crosslinked alginate hydrogels as scaffolds for tissue engineering: Part 1. Structure, gelation rate and mechanical properties. Biomaterials 2001;22:511-21.

[152] Alsberg E, Anderson K, Albeiruti A, Franceschi R, Mooney D. Cell-interactive alginate hydrogels for bone tissue engineering. J Dent Res 2001;80:2025-9.

[153] Bidarra SJ, Barrias CC, Granja PL. Injectable alginate hydrogels for cell delivery in tissue engineering. Acta Biomater 2014;10:1646-62.

[154] Dash M, Samal SK, Bartoli C, Morelli A, Smet PF, Dubruel P, et al. Biofunctionalization of ulvan scaffolds for bone tissue engineering. ACS Appl Mater Interfaces 2014;6:3211-8.

[155] Tziveleka L-A, Sapalidis A, Kikionis S, Aggelidou E, Demiri E, Kritis A, et al. Hybrid sponge-like scaffolds based on ulvan and gelatin: design, characterization and evaluation of their potential use in bone tissue engineering. Materials 2020; 13:1763.

[156] Madub K, Goonoo N, Gimié F, Arsa IA, Schönherr H, Bhaw-Luximon A. Green seaweeds ulvan-cellulose scaffolds enhance in vitro cell growth and in vivo angiogenesis for skin tissue engineering. Carbohydr Polym 2020;251:117025. 
[157] Mihaila SM, Gaharwar AK, Reis RL, Marques AP, Gomes ME, Khademhosseini A. Photocrosslinkable kappa-carrageenan hydrogels for tissue engineering applications. Adv Healthc Mater 2013;2:895-907.

[158] Tavakoli S, Kharaziha M, Kermanpur A, Mokhtari H. Sprayable and injectable visible-light Kappa-carrageenan hydrogel for in-situ soft tissue engineering. Int $J$ Biol Macromol 2019;138:590-601.

[159] Santo VE, Frias AM, Carida M, Cancedda R, Gomes ME, Mano JF, et al. Carrageenan-based hydrogels for the controlled delivery of PDGF-BB in bone tissue engineering applications. Biomacromolecules 2009;10:1392-401.

[160] Zarrintaj P, Bakhshandeh B, Rezaeian I, Heshmatian B, Ganjali MR. A novel electroactive agarose-aniline pentamer platform as a potential candidate for neural tissue engineering. Sci Rep 2017;7:1-12.

[161] Popa EG, Reis RL, Gomes ME. Seaweed polysaccharide-based hydrogels used for the regeneration of articular cartilage. Crit Rev Biotechnol 2015;35:410-24.

[162] Aizawa Y, Owen SC, Shoichet MS. Polymers used to influence cell fate in 3D geometry: new trends. Prog Polym Sci 2012;37:645-58.

[163] Guarino V, Gloria A, Raucci MG, Ambrosio L. Hydrogel-based platforms for the regeneration of osteochondral tissue and intervertebral disc. Polymers 2012;4: 1590-612.

[164] Malafaya PB, Silva GA, Reis RL. Natural-origin polymers as carriers and scaffolds for biomolecules and cell delivery in tissue engineering applications. Adv Drug Deliv Rev 2007;59:207-33.

[165] Oliveira JT, Reis R. Polysaccharide-based materials for cartilage tissue engineering applications. Tissue Eng Regen Med 2011;5:421-36.

[166] Bilal M, Iqbal H. Marine seaweed polysaccharides-based engineered cues for the modern biomedical sector. Mar Drugs 2020;18:7.

[167] Tanna B, Mishra A. Nutraceutical potential of seaweed polysaccharides: structure bioactivity, safety, and toxicity. Comp Rev Food Sci F 2019;18:817-31.

[168] Qin Y, Jiang J, Zhao L, Zhang J, Wang F. Chapter 13 - applications of alginate as a functional food ingredient. In: Grumezescu AM, Holban AM, editors. Biopolymers for food design. London: Academic Press: Elsevier; 2018. p. 409-29.

[169] Pawar SN, Edgar KJ. Alginate derivatization: a review of chemistry, properties and applications. Biomaterials 2012;33:3279-305.

[170] NotPlaLimited.

[171] Garcia Gonzalez R, Paslier P-Y. Method of encapsulating liquid products (EP3601061A1). European patent Office. 2018

[172] Ganesan AR, Shanmugam M, Bhat R. Producing novel edible films from semi refined carrageenan (SRC) and ulvan polysaccharides for potential food applications. Int J Biol Macromol 2018;112:1164-70.

[173] Guidara M, Yaich H, Richel A, Blecker C, Boufi S, Attia H, et al. Effects of extraction procedures and plasticizer concentration on the optical, thermal, structural and antioxidant properties of novel ulvan films. Int J Biol Macromol 2019;135:647-58.

[174] Guidara M, Yaich H, Benelhadj S, Adjouman YD, Richel A, Blecker C, et al. Smart ulvan films responsive to stimuli of plasticizer and extraction condition in physico-chemical, optical, barrier and mechanical properties. Int J Biol Macromol 2020;150:714-26.

[175] Market Data Bioplastics. Global production capacities of bioplastics 2018-2023. Berlin, Germany: European Bioplastics Nova Institue; 2018.

[176] Mekonnen T, Mussone P, Khalil H, Bressler D. Progress in bio-based plastics and plasticizing modifications. J Mater Chem 2013;1:13379-98.

[177] Zhang C, Show P-L, Ho S-H. Progress and perspective on algal plastics-a critical review. Bioresour Technol 2019;289:121700.

[178] Braunegg G, Lefebvre G, Genser KF. Polyhydroxyalkanoates, biopolyesters from renewable resources: physiological and engineering aspects. J Biotechnol 1998; 65:127-61.

[179] Meereboer KW, Misra M, Mohanty AK. Review of recent advances in the biodegradability of polyhydroxyalkanoate (PHA) bioplastics and their composites. Green Chem 2020;22:5519-58.

[180] Sadhukhan J, Gadkari S, Martinez-Hernandez E, Ng KS, Shemfe M, TorresGarcia E, et al. Novel macroalgae (seaweed) biorefinery systems for integrated chemical, protein, salt, nutrient and mineral extractions and environmental protection by green synthesis and life cycle sustainability assessments. Green Chem 2019;21:2635-55.

[181] Bharathiraja B, Chakravarthy M, Kumar RR, Yogendran D, Yuvaraj D, Jayamuthunagai J, et al. Aquatic biomass (algae) as a future feed stock for biorefineries: a review on cultivation, processing and products. Renew Sustain Energy Rev 2015;47:634-53.

[182] Gegg P, Wells V. UK macro-algae biofuels: a strategic management review and future research agenda. J Mar Sci Eng 2017;5:32.

[183] Balat M, Balat H, Öz C. Progress in bioethanol processing. Prog Energy Combust Sci 2008:34:551-73.

[184] Dave N, Selvaraj R, Varadavenkatesan T, Vinayagam R. A critical review on production of bioethanol from macroalgal biomass. Algal Research 2019;42: 101606.

[185] Nguyen TH, Ra CH, Sunwoo I, Jeong G-T, Kim S-K. Bioethanol production from Gracilaria verrucosa using Saccharomyces cerevisiae adapted to $\mathrm{NaCl}$ or galactose. Bioproc Biosyst Eng 2017;40:529-36.

[186] Al Abdallah Q, Nixon BT, Fortwendel JR. The enzymatic conversion of major algal and cyanobacterial carbohydrates to bioethanol. Front Energy Res 2016;4:36.

[187] Ji S-Q, Wang B, Lu M, Li F-L. Direct bioconversion of brown algae into ethanol by thermophilic bacterium Defluviitalea phaphyphila. Biotechnol Biofuels 2016;9:81.

[188] Enquist-Newman M, Faust AME, Bravo DD, Santos CNS, Raisner RM, Hanel A, et al. Efficient ethanol production from brown macroalgae sugars by a synthetic yeast platform. Nature 2014;505:239-43.
[189] Eisentraut A. Sustainable production of second-generation biofuels: potential and perspectives in major economies and developing countries. IEA Energy Papers 2010. 01.

[190] Werpy T, Petersen G. Top value added chemicals from biomass: volume I-results of screening for potential candidates from sugars and synthesis gas. 2004.

[191] Bozell JJ, Petersen GR. Technology development for the production of biobased products from biorefinery carbohydrates - the US Department of Energy's "Top 10" revisited. Green Chem 2010;12:539-54.

[192] Ramesh T, Kalaiselvam M. An experimental study on citric acid production by Aspergillus niger using Gelidiella acerosa as a substrate. Indian J Microbiol 2011; 51:289-93.

[193] Alvarado-Morales M, Gunnarsson IB, Fotidis IA, Vasilakou E, Lyberatos G, Angelidaki I. Laminaria digitata as a potential carbon source for succinic acid and bioenergy production in a biorefinery perspective. Algal Res 2015;9:126-32.

[194] Marinho GS, Alvarado-Morales M, Angelidaki I. Valorization of macroalga Saccharina latissima as novel feedstock for fermentation-based succinic acid production in a biorefinery approach and economic aspects. Algal Res 2016;16: 102-9.

[195] Olajuyin AM, Yang M, Liu Y, Mu T, Tian J, Adaramoye OA, et al. Efficient production of succinic acid from Palmaria palmata hydrolysate by metabolically engineered Escherichia coli. Bioresour Technol 2016;214:653-9.

[196] Mazumdar S, Bang J, Oh M-K. L-Lactate production from seaweed hydrolysate of Laminaria japonica using metabolically engineered Escherichia coli. Appl Biochem Biotechnol 2014;172:1938-52.

[197] Jang S-S, Shirai Y, Uchida M, Wakisaka M. Potential use of Gelidium amansii acid hydrolysate for lactic acid production by Lactobacillus rhamnosus. Food Technol Biotechnol 2013;51:131-6.

[198] Mazumdar S, Lee J, Oh M-K. Microbial production of 2, 3 butanediol from seaweed hydrolysate using metabolically engineered Escherichia coli. Bioresour Technol 2013;136:329-36.

[199] Bikker P, van Krimpen MM, van Wikselaar P, Houweling-Tan B, Scaccia N, van Hal JW, et al. Biorefinery of the green seaweed Ulva lactuca to produce animal feed, chemicals and biofuels. J Appl Phycol 2016;28:3511-25.

[200] Moriya H, Takita Y, Matsumoto A, Yamahata Y, Nishimukai M, Miyazaki M, et al. Cobetia sp. bacteria, which are capable of utilizing alginate or waste Laminaria sp. for poly (3-hydroxybutyrate) synthesis, isolated from a marine environment. Front Bioeng Biotechnol 2020;8:974.

[201] Taylor R, Nattrass L, Alberts G, Robson P, Chudziak C, Bauen A, et al. From the sugar platform to biofuels and biochemicals: final report for the European Commission Directorate-General Energy. 2015.

[202] Cesário MT, da Fonseca MMR, Marques MM, de Almeida MCM. Marine algal carbohydrates as carbon sources for the production of biochemicals and biomaterials. Biotechnol Adv 2018;36:798-817.

[203] Arnaud-Haond S, Arrieta JM, Duarte CM. Marine biodiversity and gene patents. Science 2011;331:1521-2.

[204] Circuncisão AR, Catarino MD, Cardoso SM, Silva A. Minerals from macroalgae origin: health benefits and risks for consumers. Mar Drugs 2018;16:400.

[205] Cornish ML, Mouritsen OG, Critchley AT. A mini-review on the microbial continuum: consideration of a link between judicious consumption of a varied diet of macroalgae and human health and nutrition. J Oceanol Limnol 2019;37: 790-805.

[206] Laurens LM, Lane M, Nelson RS. Sustainable seaweed biotechnology solutions for carbon capture, composition, and deconstruction. Trends Biotechnol 2020.

[207] Chisti Y. Constraints to commercialization of algal fuels. J Biotechnol 2013;167: 201-14.

[208] Gerbens-Leenes W, Hoekstra AY. The water footprint of sweeteners and bioethanol. Environ Int 2012;40:202-11.

[209] Gerbens-Leenes W, Hoekstra AY, van der Meer TH. The water footprint of bioenergy. Proc Natl Acad Sci Unit States Am 2009;106:10219-23.

[210] Greetham D, Adams JM, Du C. The utilization of seawater for the hydrolysis of macroalgae and subsequent bioethanol fermentation. Sci Rep 2020;10:1-15.

[211] Jones ES, Raikova S, Ebrahim S, Parsons S, Allen MJ, Chuck CJ. Saltwater based fractionation and valorisation of macroalgae. J Chem Technol Biotechnol 2020.

[212] Zaky AS, French CE, Tucker GA, Du C. Improving the productivity of bioethanol production using marine yeast and seawater-based media. Biomass Bioenergy 2020;139:105615.

[213] Zaky AS, Greetham D, Tucker GA, Du C. The establishment of a marine focused biorefinery for bioethanol production using seawater and a novel marine yeast strain. Sci Rep 2018;8:1-14.

[214] Rosen MA. Environmental sustainability tools in the biofuel industry. Biofuel Research Journal 2018;5:751-2.

[215] Krumhansl KA, Okamoto DK, Rassweiler A, Novak M, Bolton JJ, Cavanaugh KC, et al. Global patterns of kelp forest change over the past half-century. Proc Natl Acad Sci Unit States Am 2016;113:13785-90.

[216] Pineiro-Corbeira C, Barreiro R, Cremades J. Decadal changes in the distribution of common intertidal seaweeds in Galicia (NW Iberia). Mar Environ Res 2016;113: $106-15$.

[217] Borja Á, Fontán A, Muxika I. Interactions between climatic variables and human pressures upon a macroalgae population: implications for management. Ocean Coast Manag 2013;76:85-95.

[218] Sjøtun K, Husa V, Asplin L, Sandvik AD. Climatic and environmental factors influencing occurrence and distribution of macroalgae a fjord gradient revisited. Mar Ecol Prog Ser 2015;532:73-88.

[219] Martínez B, Radford B, Thomsen MS, Connell SD, Carreño F, Bradshaw CJ, et al. Distribution models predict large contractions of habitat-forming seaweeds in response to ocean warming. Divers Distrib 2018;24:1350-66. 
[220] Wiersma B, Devine-Wright P. Public engagement with offshore renewable energy: a critical review. Wiley Interdiscip Rev Clim Change 2014;5:493-507.

[221] Yaich H, Garna H, Bchir B, Besbes S, Paquot M, Richel A, et al. Chemical composition and functional properties of dietary fibre extracted by Englyst and Prosky methods from the alga Ulva lactuca collected in Tunisia. Algal Res 2015;9: 65-73.

[222] Lechat $H$. Nature et organisation des polysaccharides parietaux de l'algue rouge eucheuma cottonii. Thèse de doctorat de l'Université de Nantes; 1998.
[223] Lechat H, Amat M, Mazoyer J, Buléon A, Lahaye M. Structure and distribution of glucomannan and sulfated glucan in the cell walls of the red alga Kappaphycus alvarezii (Gigartinales, Rhodophyta). J Phycol 2000;36:891-902.

[224] Michel G, Tonon T, Scornet D, Cock JM, Kloareg B. The cell wall polysaccharide metabolism of the brown alga Ectocarpus siliculosus. Insights into the evolution of extracellular matrix polysaccharides in Eukaryotes. New Phytol 2010;188: $82-97$. 